\title{
COP26 Futures We Want - India Country Profile
}

The purpose of this region profile was to provide an evidence base to inform the production of Net Zero Future visions. A consolidated version of material contained here was used as stimulus for in-country workshops and creative translational approaches that developed a plausible vision for each country. This document provides a selection of relevant evidence for the sectors and themes identified through the scoping exercise.

\section{Part A: Executive summary}

This country profile for India has been developed with the input from in-country academic experts, including Prof Ambuj Sagar and Dr Suresh Babu, in the BEIS COP26 Visions for a Net Zero Future project. It sets out a synthesis of the available evidence base on regional challenges and opportunities for mitigation, adaptation, and resilience measures for India associated with climate change and a global transition to an inclusive, desirable, resilient net-zero future.

India presents a unique and complex set of challenges for tackling climate change and approaching a net-zero future. As per the country's ratification to the Paris Agreement, it has committed to bringing its greenhouse gas (GHG) emissions to $33 \%-35 \%$ by 2030 below 2005 levels, increase the share of non-fossil-based energy resource to $40 \%$ of installed electric power capacity by 2030 and to create an additional (cumulative) carbon sink of 2.5-3 $\mathrm{GtCO}_{2}$ e through additional forest and tree cover by 2030. However, India does not specify the coverage and metrics of the emissions intensity target in its NDC.

India has made considerable progress in its efforts towards decoupling economic growth from GHG emissions. According to the third Biennial Report submitted to the United Nations Framework Convention on Climate Change (UNFCCC) in February 2021, India's emission intensity of gross domestic product (GDP) has reduced by 24 $\%$ between 2005 and 2016 , thereby achieving its voluntary goal to reduce the emission intensity of GDP by $20-25 \%$ from 2005 levels, earlier than the target year of 2020 .

Setting an economy-wide net-zero target will be challenging. However, given that the development priorities of the vast majority of its population are yet to be met, it is important that India sets a net-zero target in a manner that also supports its development priorities. Over half of the country's population is dependent on climatesensitive sectors for their livelihoods, making India one of the most vulnerable countries to the impacts of climate change. The associated short-term and long-term socio-economic impacts of a net-zero transition needs a detailed analysis.

India's $\mathrm{CO}_{2}$ sink through land use, land-use change, and forestry (LULUCF) rose by approximately $40 \%$ between 2000 and $2016^{1}$. Forest and tree cover sequestered 331 $\mathrm{MtCO}_{2}$ in 20161, around $15 \%$ of total $\mathrm{CO}_{2}$ emissions occurring in the country. Perform, Achieve and Trade (PAT) scheme for energy efficiency in industries and other energyintensive sectors avoided $61.34 \mathrm{MtCO}_{2}$ between $2012-2019^{1}$. Besides mitigation, it is a priority that India sets out comprehensive action points to address adaptation, finance, technology transfer, capacity building and transparency of action and support. 
There is a need to strengthen international cooperation to move India on an accelerated and just pathway towards decarbonisation.

India's most pressing climate risks up to 2050 involve flooding, heatwaves, droughts, water scarcity, extreme precipitation, and the many complex interdependencies between physical risks. An example of this complex interdependency at play the increased risk of vector-borne diseases due to rising temperatures, food and nutrition security and livelihood loss.

The current focus of government action lies in the opportunities of electrification, energy efficiency, and the enhanced use of biofuels in the transport sector. More efforts are required to establish a robust supply chain and infrastructure for decarbonising the transportation sector. Further research and development in battery storage, hydrogen technology, and second and third-generation biofuels are needed to achieve emission reduction targets in the transport sector.

India will more than double its building space over the next two decades, with $70 \%$ of building stock still to be constructed in urban areas. Enhancing energy efficiency and renewable integration can help mitigate the surge in building-related energy demand. New construction in urban areas will also be a key driver for energy-intensive material demand. For example, the demand for cement and steel is set to double by $2040^{2}$.

Adaptation is critical for India and requires urgent action. At the same time, there is need to plan fair mitigation strategies across India's complex demographics. Greater uptake of nature-based solutions can provide a range of environmental, social and economic benefits while combatting the accelerating loss of biodiversity.

This profile is structured into three sections: 1. Country context, covering economic and development context, and current greenhouse gas emissions; 2. Physical climate change, covering risks, adaptation, and opportunities; and 3. Development-compatible transition, covering risks, mitigation, and opportunities. The latter half of section 3 focuses on priority sectors/themes for development compatible transition in the region, including agriculture, buildings, electricity generation, nature-based solutions and surface transport.

\section{Part B: Expert Committee Inputs}

\section{Country Context}

\section{1.a Economic Context}

\section{1.a.i Sectors that contribute most to the country's GDP}

Between 2009-2019, India's predominant economic sector was services accounting for $54.77 \%$ of GDP in $2019^{3}$. Agriculture accounted for $17.76 \%$ of GDP and industry $27.47 \%$ (see Figure 1). 


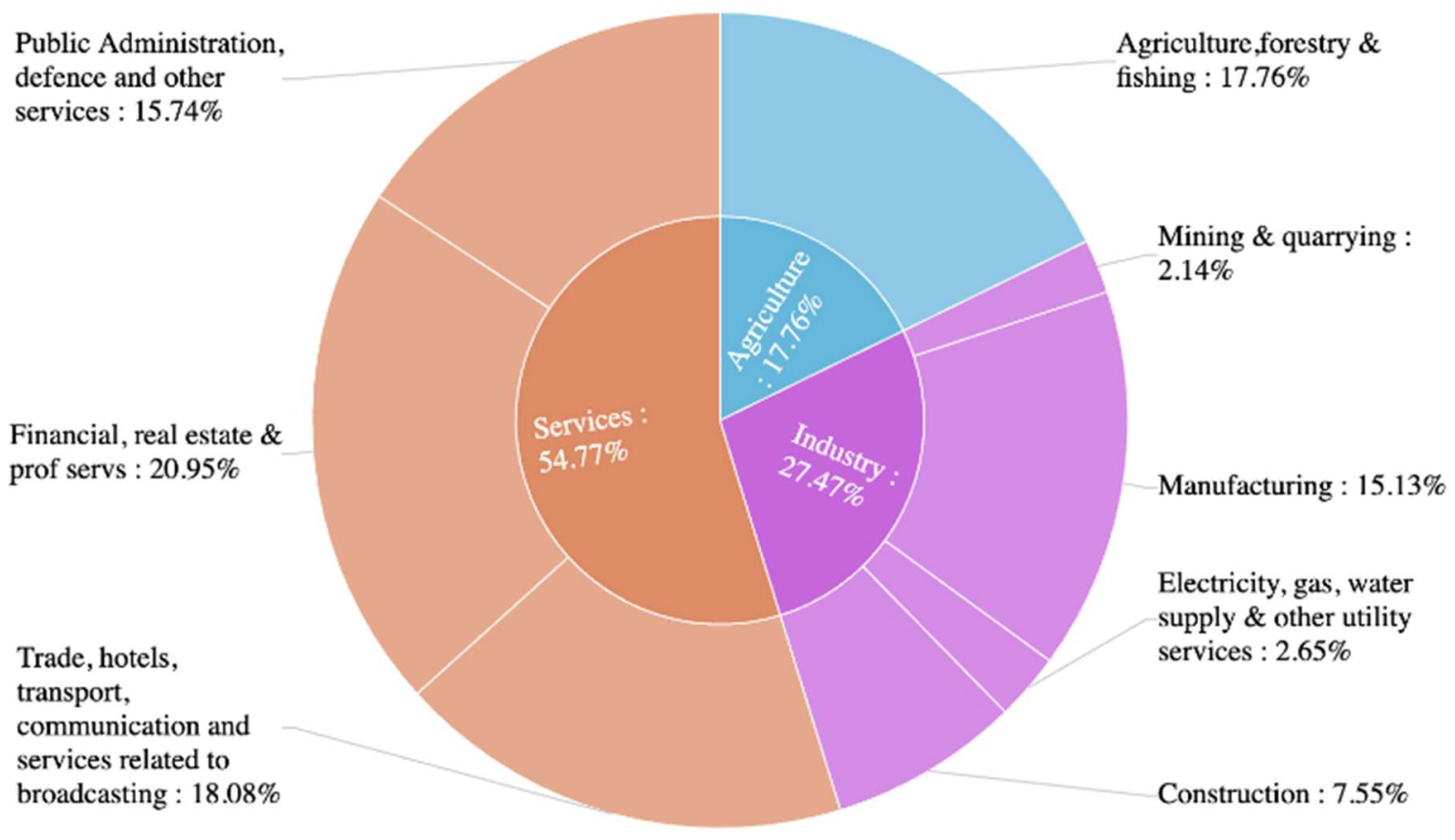

Figure 1:1 India economy, GDP by sectors, 2019-20 (source:3)

\section{1.a.ii Sectors that represent growth areas for the country economically (in absolute terms, but also as a proportion of GDP)}

NITI Aayog, a public policy think-tank of the Indian government, stresses five growth drivers for India: employment; doubling farmers' income; 'Make in India' (manufacturing); science, technology and innovation (STI); fintech and tourism (F\&T) ${ }^{4}$. India is expecting a V-shaped recovery from the pandemic crisis, with strong rebound in manufacturing and several services sectors, while the agriculture sector continues to perform steadily ${ }^{5}$.

India's manufacturing sector is developing fast. The healthcare industry will grow over $£ 40$ billion by 2022 . The entertainment and media sector reached around $£ 17.8$ billion in 2018 - creating a lucrative market for technology businesses with smart IP6.

The Indian Government's 'Make in India' campaign is aggressively changing focus to fostering investment, innovation, protecting intellectual property, and building best-inclass manufacturing infrastructure ${ }^{6,7}$. Significant effort is being placed on green technology in automotive manufacturing ${ }^{8}$. Digital innovation-driven services is a rapidly growing sector that is creating a demand for financial services, broadband infrastructure, e-identity solutions (like Aadhar card) and cloud technology.

India's energy market represents robust growth opportunities following the Indian government's net-zero renewable target of $450 \mathrm{GW}$, which will require an investment 
of $£ 216$ billion by $2030^{9}$. Financial, legal and professional services are growing at $105 \%$ annually since $2014^{7}$. Infrastructure development associated with smart city and housing for all programs are aggressively growing sectors, especially roads, ports, airports, power (including nuclear), rail, new cities and towns. NITI Aayog further emphasises the opportunities for development of infrastructure for water resources, sustainable environment, land resource and land-use planning and data-driven governance ${ }^{2}$.

\section{1.a.iii. Major trade-flows (goods and services) in and out of the country today}

In 2019, India was a net importer of goods, with imports exceeding exports by $£ 102 B$. India's total global exports equalled £223B. The top exports of India are refined petroleum (£28.1B), diamonds ( £18.2B), packaged medicaments ( £11.2B), jewellery $(£ 9.9 \mathrm{~B})$, cars $(£ 5.1 \mathrm{~B})$, rice $(£ 4.9 \mathrm{~B})$, crustaceans $(£ 3.3 \mathrm{~B})$, and non-retail pure cotton yarn (£2B) exporting mostly to United States (£39.05B), United Arab Emirates (£20.20B), China (£12.29B), Hong Kong (£8.12B), and Singapore $(£ 6.73 B)^{10}$ (Figure 2).

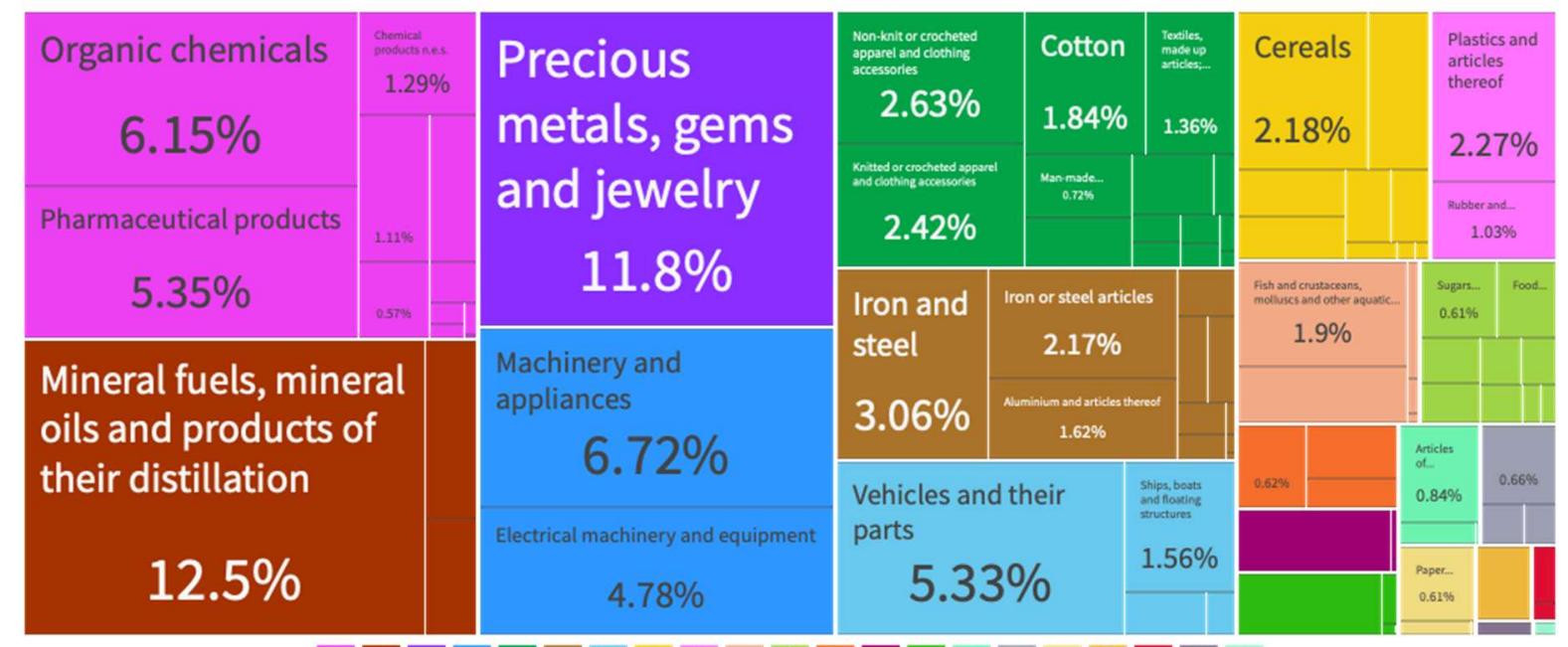

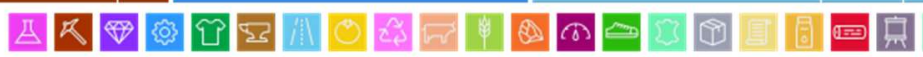

Figure 2: 2 India exports (good) 2019. In 2019, exports totalled more than £223B, $18.41 \%$ of the country's GDP that year (source: The Observatory of Economic Complexity $\left.{ }^{10}\right)$.

In 2019, India's global imports equalled £335B. The top imports are crude petroleum products (£65.4B), gold (£23.8B), coal briquettes (£17.5B), diamonds (£15.1B), petroleum gas (£11.5B), palm oil (£3.4B), nitrogenous fertilizers (£1.9B) and soybean oil (£1.6B), importing mostly from China (£51.2B), United States (£23.8B), United Arab Emirates (£18.9B), Saudi Arabia (£27.7B), and Iraq $(£ 13.9 B){ }^{10}$ (see Figure 3). 


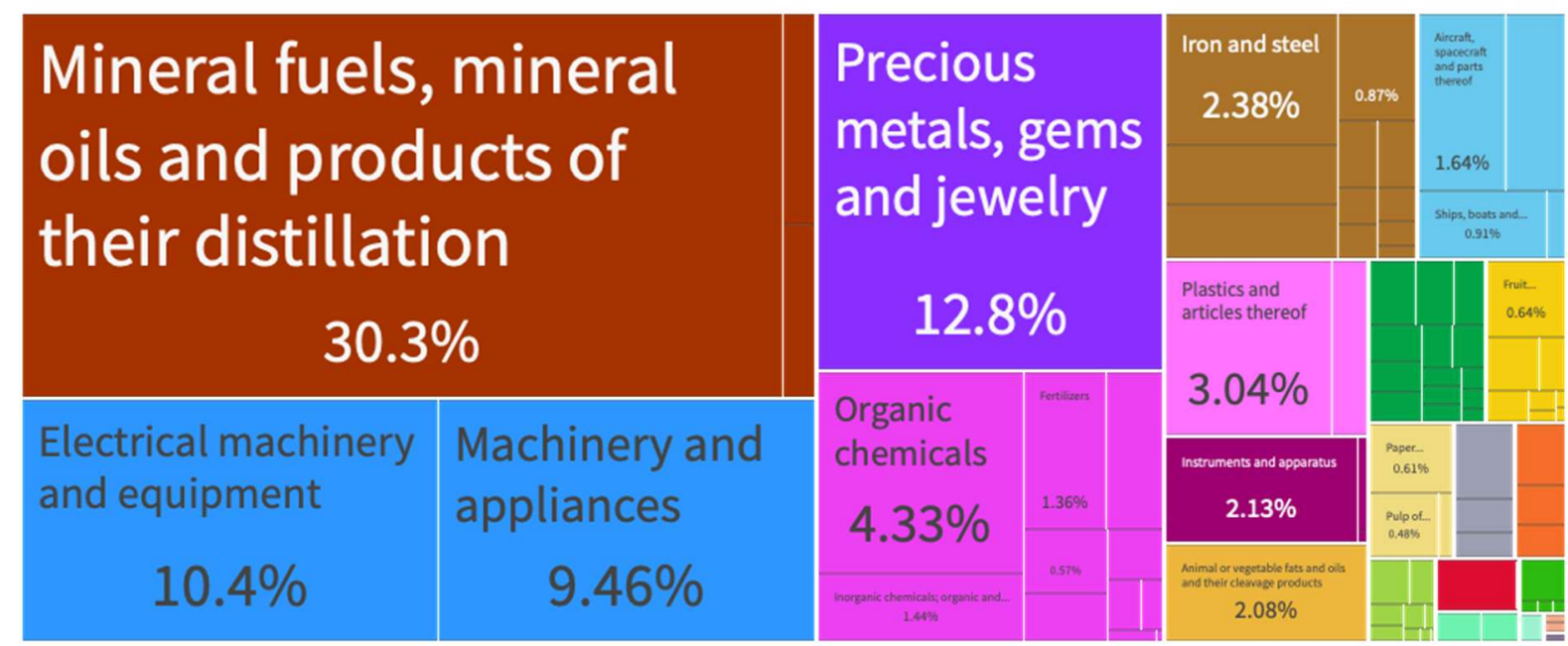

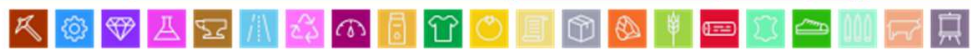

Figure 3: Imports to India (goods) 2019. In 2019, imports totalled more than £335B, making India a net importer (source: The Observatory of Economic Complexity ${ }^{10}$ ).

In 2018, India exported £84.04B worth of services. The top services exported were miscellaneous business, professional, and technical services (\$34.9B), Personal travel (£18.36B), Other government services (£13.42B), sea transport (£8.97B), and air transport $(£ 4.07 \mathrm{~B})^{10}$.

\section{1.b Development Context}

\section{1.b.i What are the key development indices for this country?}

India's HDI value for 2019 is 0.645 - which put the country in the medium human development category-positioning it at 131 out of 189 countries and territories. Between 1990 and 2019, India's HDI value rose from 0.429 to 0.645 , an increase of $50.3 \%{ }^{11}$. In the same period, India's life expectancy at birth increased by 11.8 years, mean years of schooling increased by 3.5 years and expected years of schooling increased by 4.5 years ${ }^{11}$. India's GNI per capita increased by about 273.9 percent between 1990 and $2019^{11}$.

\section{1.b.ii What are the priorities and barriers to enabling the country's sustainable, inclusive and resilient growth?}

India's National Action Plan on Climate Change (NAPCC) encompasses both climate protection and adaptation ${ }^{12}$. It defines eight priorities as 'National Missions': solar energy; energy efficiency; sustainable housing; water; preservation of ecosystem in the Himalayas; reforestation; sustainable agriculture; and strategic knowledge management ${ }^{12}$. Adaptation measures are an important part of this integrated climate strategy. The first two areas (solar energy and energy efficiency) are mainly focused on climate protection, while the others include adaptation components, especially in the cases of agriculture and knowledge management ${ }^{13,14}$. 


\section{1.c Development compatible greenhouse gas emissions (GHGs)}

\section{1.c.i Country's current GHG emissions profile}

- Territorial emissions (2019): 2.62 gigaton of carbon dioxide $\left(\mathrm{GtCO}_{2}\right)$, of which $1.67 \mathrm{Gt}$ from coal, 627.91 megaton (Mt) from oil, $143.66 \mathrm{Mt}$ from cement, $128.68 \mathrm{Mt}$ from gas and $1.58 \mathrm{Mt}$ from flaring ${ }^{15}$. Agriculture is the second largest contributor to emissions in India with 718.70Mt in 2018.

- Consumption emissions (2018): $2.35 \mathrm{GtCO}_{2}{ }^{15}$

- Emissions per GDP: 1243.93 tCO 2 e/ million\$ GDP (2018) ${ }^{16}$

- Emissions per capita (Figure 4): $1.91 \mathrm{tCO}_{2} /$ person $(2019)^{16}, 0.50 \mathrm{tCH}_{4} /$ person, $0.19 \mathrm{tN}_{2} \mathrm{O} /$ person

\section{Per capita $\mathrm{CO}_{2}$ emissions}

Carbon dioxide $\left(\mathrm{CO}_{2}\right)$ emissions from the burning of fossil fuels for energy and cement production. Land use change is not included.

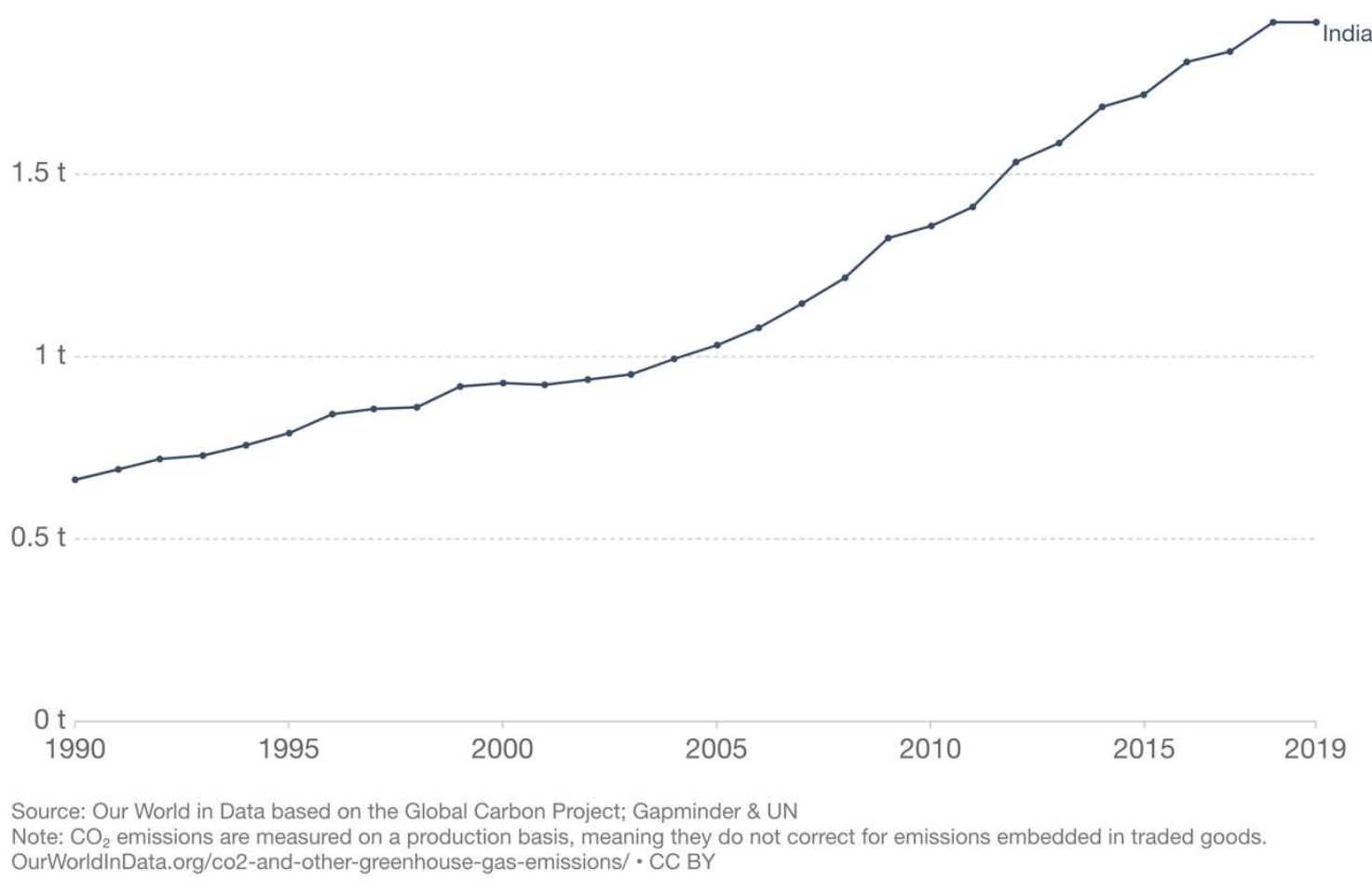

Figure 4: Per Capita $\mathrm{CO}_{2}$ Emissions for India, 1990-2019. Figure from: Our World in Data.

1.c.ii Sector-specific GHG emissions from the sectors which are key for development in this country 
Breakdown of total greenhouse gas emissions by sector, measured in tonnes of carbon-dioxide equivalents $\left(\mathrm{CO}_{2} \mathrm{e}\right)$. Carbon dioxide equivalents measures the total greenhouse gas potential of the full combination of gases, weighted by their relative warming impacts.

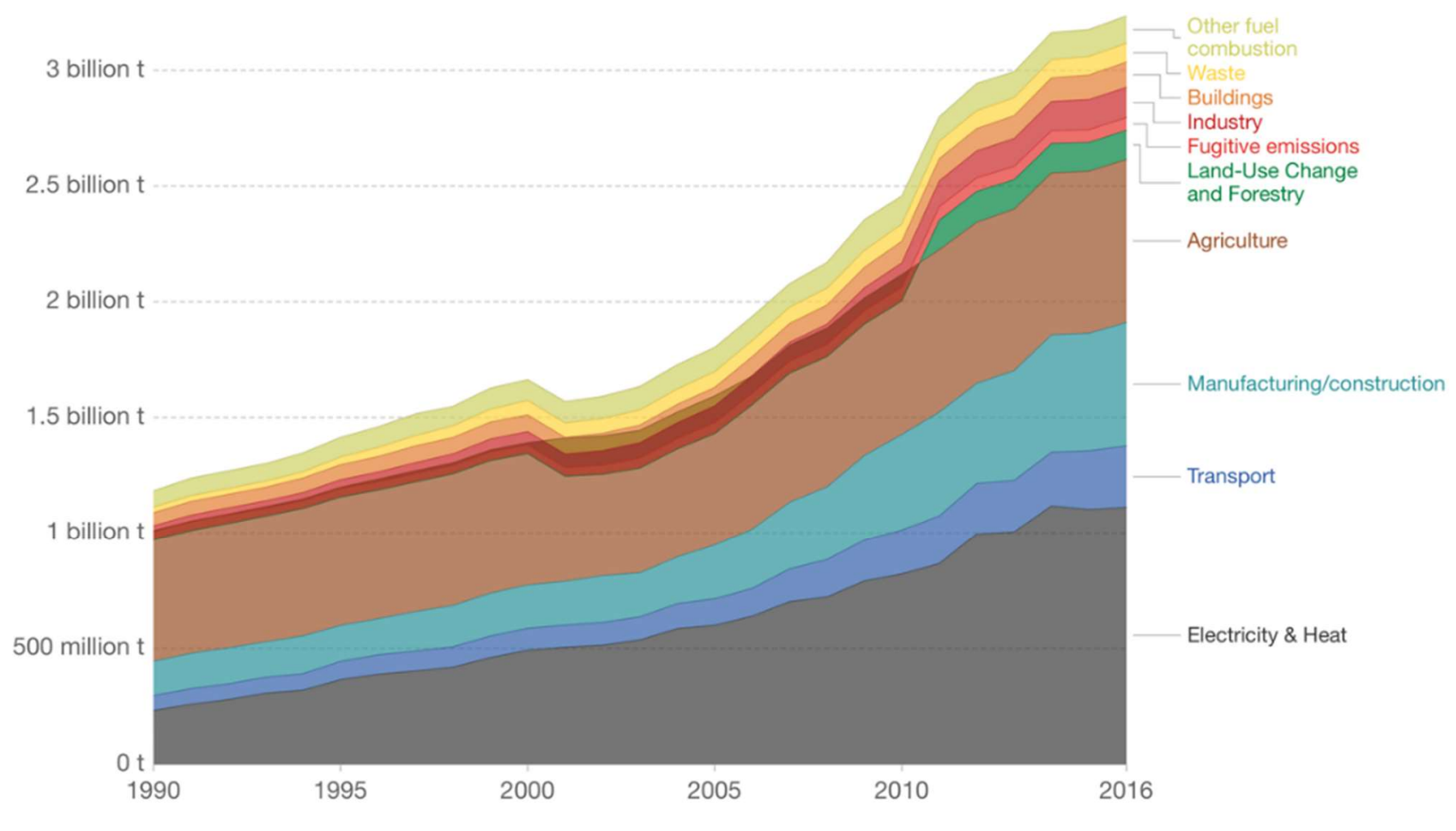

Figure 5: GHG emissions by sector for India (1990 - 2016). Figure from: Our World in Data.

India's greenhouse gas emitting sectors (carbon-dioxide equivalent, $\mathrm{CO}_{2} \mathrm{e}$ or $\mathrm{GHGe}$ ) are aggregated in Figure 5. Energy was the largest sector at $2.42 \mathrm{Gt}$, with electricity as the largest contributor to this sector $(1.24 \mathrm{Gt})^{16}$. It was followed by agriculture (718.70Mt), manufacturing/construction (571.38Mt) and transportation (305.33Mt). Flaring (other fuel combustion) contributed to $133.28 \mathrm{Mt}$ and the building sector corresponded $118.84 \mathrm{Mt}^{16}$. Land-use change, and forestry sequestered $28.36 \mathrm{Mt}$ in $2018^{16}$.

\section{Physical climate change - risks, adaptation and opportunities}

\section{2.a Physical climate risk profile}

\section{2.a.i Physical climate risks that the country is already facing.}

In recent years India experienced various extreme weather events like heatwaves, floods and tropical storms ${ }^{15}$. There has been an observed decrease in mean rainfall over most parts of the eastern and central north regions of India during 1973 - 2019 due to interannual variability in monsoon caused by changes in the Indian Ocean and Arabian Sea temperature and moisture content. Change in land cover and noticeable reduction in vegetation cover also contributed to the decrease in rainfall ${ }^{17}$. A heatwave 
during the 2016 drought left much of northern India above $40^{\circ} \mathrm{C}$ for weeks ${ }^{18}$. In 2015 , it was reported that heatwave claimed over 2500 lives in India, although unreported death may be much higher. Risks include increased heat stress-related mortality and morbidity, particularly in urban areas and among agricultural workers ${ }^{19,20}$. Flood risk is increasing in the country's interior, including in the capital Delhi, and along both coasts due to the combination of increasing intensity and frequency of heavy rainfall events, sea level rise and poorly managed urban development ${ }^{21-23}$. Flood-related mortality and morbidity has increased, including a rise in gastrointestinal disease from degraded water quality ${ }^{24,25}$. Increase in temperature and greater precipitation have expanded transmission windows for malaria and dengue ${ }^{26}$.

Based on India's National Communication, NAPCC and available literature, India's most vulnerable sectors to the effects of climate change are water, agriculture and food security, forests, natural ecosystems, public health, and energy security ${ }^{12,14}$. The anticipated future impacts of climate change identified by the Indian government are, i) decreased snow cover (with precipitation falling as rain instead of snow), affecting snow-fed and glacial systems such as the Ganges and Brahmaputra ${ }^{27}$; ii) erratic monsoons with serious effects on rain-fed agriculture, peninsular rivers, water and power supply; iii) decline in wheat production by 4-5 million tonnes with as little as a $1^{\circ} \mathrm{C}$ rise in temperature from 2010 levels; iv) rising sea levels causing displacement along one of the most densely populated coastlines in the world and threatening freshwater sources and mangrove ecosystems; v) increased frequency and intensity of floods; increased vulnerability of people in coastal, arid and semi-arid zones of the country; vi) over $50 \%$ of India's forests are likely to experience a shift in forest types, adversely impacting associated biodiversity and regional climate dynamics, as well as livelihoods based on forest products ${ }^{12,14}$. For the more than 800 million Indians who live in rural areas and depend on climate-sensitive sectors for their livelihoodsagriculture, forests and fisheries-the future looks alarming with the prospect of declining crop yields, degraded lands, water shortages and ill health ${ }^{12,14}$.

In India, climate-sensitive rainfed agriculture accounts for $60 \%$ of cultivated area and $40 \%$ of national production ${ }^{17,28,29} \mathrm{r}$. Increasing temperatures and more severe dry seasons are likely to exacerbate drought impacts ${ }^{29}$. By 2030, India's agriculture sector is expected to suffer more than $\$ 7$ billion of annual losses due to drought alone ${ }^{30}$. A $1^{\circ} \mathrm{C}$ rise in temperature from 2010 levels will put strain on India's nutrient security ${ }^{29-}$ 31. Risks from increased temperatures include reduced grain yields and quality due to heat stress; reduced plantation productivity where temperature thresholds are exceeded, and diminished milk production due to heat stress ${ }^{30,32-34}$. The frequency of heavy precipitation events has increased over India, while the frequency of moderate rain events has decreased since $1950^{30,35}$ More extreme rainfall events and severe dry season effects make smallholding farmers particularly vulnerable to degraded crops and pastureland from flooding, erosion and drying ${ }^{30,35}$. Sea level rise risks storm surges, saltwater inundation and intrusion, impacting coastal aquaculture and agricultural land productivity ${ }^{36}$. 
Risks from increased temperature on the ecosystem include reduced and shifted ranges for species, leading to biodiversity loss ${ }^{29,37}$. Increased frequency of regional droughts may shift forest covers, especially affecting central and western India ${ }^{15,35}$. More severe dry seasons can lead to increased forest degradation from wildfires, impacting biodiversity and forest-dependent livelihoods ${ }^{37-40}$. Sea level rise will cause degradation/loss of coastal wetland habitats and mangroves ${ }^{41,42}$.

India's water resources are considerably stressed due to population growth, increased production of water-intensive crops, pollution and lack of government planning ${ }^{43}$. Glacial melt, due to temperature increases and the role played by black carbon, leads to flooding and water logging ${ }^{44}$, while increased evaporation and decreased precipitation in Central and Northern India are expected to raise the risk of drought $23,45,46$. In urban areas, projected increased flooding due to heavy rainfall is expected to stress sewerage and drainage infrastructure, leading to the higher risk of water contamination ${ }^{36,47,48}$. In coastal aquifers, reduced freshwater flows during drought may increase the risk of saline intrusion, which may be further exacerbated by sea level rise ${ }^{47,49}$.

\section{2.a.ii How these risks are likely to change by 2050 due to climate change}

Annual probability of a lethal heat wave, ${ }^{1} \%$

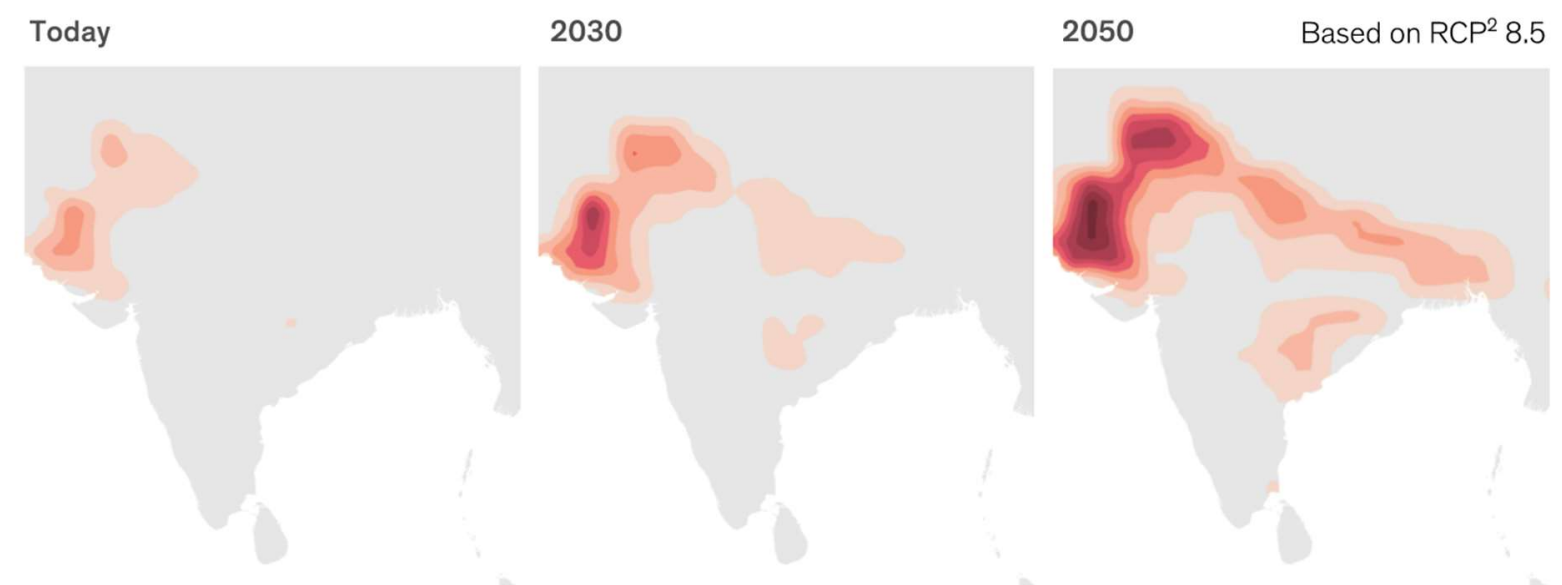

Figure 6: Annual probability of lethal heatwave ( $>35 \mathrm{C}$ wet-bulb temperature) in India is expected to increase between 2018 and 2050 (source:50).

By 2050, India could become one of the first places in the world to experience heat waves that cross the survivability limit for a healthy human resting in the shade ${ }^{50,51}$ (see Figure 6). Rising heat and humidity levels will impact labour productivity and economic growth, affecting lives of around $310-480$ million people ${ }^{51}$. Rising temperatures and changing monsoon rainfall patterns are estimated to cost India $2.8 \%$ of GDP and 
depress the living standards of nearly half the country's population by $2050^{51,52}$. Extreme heat will also decrease the capacity for outdoor work by $15 \%$ during daylight hours ${ }^{52}$.

It is also estimated that as many as 160,000 people could die every year in India by 2050 due to a decrease in food production ${ }^{53}$ arising from shifts in the timing and amount of monsoon rain ${ }^{54}$. Compounded with heatwave events, this means the morbidity and mortality may be very significantly higher than the current levels ${ }^{53}$. More than 36 million Indians could lose their homes and livelihoods to flooding due to rising sea levels, and more intense monsoon rainfall, with impacts concentrated in megacities like Mumbai, Kolkata, Chennai and Kochi ${ }^{36,55}$. A recent modelling study showed that an increase of $20-30 \%$ in the potential for more severe storms (especially tropical cyclones) will cause more damage to infrastructure and livelihoods, and further intensify saltwater intrusions in storm surges ${ }^{56}$.

\section{2.a.iii What additional long-term climate risks might be incurred before $\mathbf{2 1 0 0}$}

India's second national communication to UNFCCC in $2012^{29}$ projected climate change and climate variability to impact water resources with increasing severity through the century. The impacts are likely to affect irrigated agriculture, installed power capacity, environmental flows in the dry season and higher flows during the wet season, thereby causing severe droughts and flood problems in urban and rural areas $^{29}$. Estimation show that forest conservation efforts can increase the Net Primary Productivity (NPP) of forests by $56.2 \%$ by $2085^{29}$. However, increased pressure from anthropogenic activities, livestock grazing, insect and pest outbreaks, forest fires make conservation efforts challenging in coming years.

There are likely to be significant health impacts due to increased heat stress-related morbidity and mortality, with likely 50 - 150 days per year where temperatures exceed the heat stress threshold of $41^{\circ} \mathrm{C}^{17,29}$. India is projected to see a $10 \%$ increase of death rates due to climate change compared to current death rates in 2019. These include a likely expansion of transmission windows by 2-3 months in northern India for malaria and dengue with increased temperature and precipitation. Pathogen load for gastrointestinal disease from degraded water quality is expected to increase due to warming trends favouring pathogen growth, increased rainfall and extreme precipitation (straining sanitation systems and distributing pathogens), and drought (causing people to resort to low-quality water sources) ${ }^{26,29,32}$.

It is predicted that at least one third of the region's glaciers will melt by 2100 , even if average global temperature rises are limited to $1.5^{\circ} \mathrm{C}$. This melting will reduce available water for agriculture and impact the region's food security and also increase the risk of flash flooding due to glacial burst ${ }^{27,57-59}$. Heatwaves will further intensify 
from 2050 baselines, affecting livelihood of around 600 million Indians by $2100^{60}$. One study by the Asian Development Bank estimated that India could see economic losses of up to $8.7 \%$ of GDP by 2100 due to the impacts of climate change ${ }^{42}$.

2.a.iv How might different physical, sociological and economic risks and vulnerabilities interact? (correlated and cascading risks, multiple interacting risks, interconnectivity between these different physical climate risks)

All climate risks and opportunities in India are interdependent on the diversity of the country. Not every socioeconomic group will be impacted equally or in a similar way, which itself is one of the greatest mitigation and adaption challenges for the country ${ }^{12,29}$. There are interdependencies across heatwaves and public health, especially through increase in vector-borne diseases like malaria, dengue and diarrhoea 26,29 .

There is also an estimation of $15 \%$ loss of labour productivity from 2020 levels due to heat-stress by $2030^{50}$. The rising temperature is also set to significantly affect agricultural productivity, putting millions of smallholder farmer's livelihood at risk. There are added risks from an increase in crop damage due to pest/insects, and nutrition security ${ }^{31}$. The loss of nutrition from staple crops like rice, wheat, millet and legumes will particularly impact child malnutrition ${ }^{17,31,60}$.

Saline intrusion into topsoil in low-lying areas due to sea level rise will further impact agriculture and productivity affecting millions of livelihoods. Warming trends will increase heat stress on dairy animals (mainly water buffaloes and cows), leading to a decrease in milk production of up to 15 million tons annually by $2050^{17,60}$. Forest cover is expected to shift to drier forest types that will increase the incidents of forest fires $^{39,61,62}$. Significant changes in forest cover would impact the 275 million people, including many indigenous communities, who are directly dependent on forests for their livelihoods ${ }^{40}$. Climate change impacts on agriculture and livelihoods can increase the number of climate refugees ${ }^{63}$.

Melting of Himalayan glaciers will impact more than 660 million Indians through changes to water availability and flood risk. Urban areas will see changes in climate variability, with frequent flooding events affecting most of Indian megacities ${ }^{17,21}$, compromising their sustainable development. Changes in waterflow will also impact India's energy security by placing severe stress on hydropower and thermal power generation infrastructure ${ }^{63}$.

The increased risk of vector-borne diseases also possesses a significant economic problem that could hamper India's development. A 2017 study put the economic cost of malaria alone at US\$1940 million, with the $75 \%$ due to lost earning and $25 \%$ due to 
treatment costs ${ }^{64}$. With rising temperatures increasing the transmission rates of vector-borne diseases, the economic cost to households as well as India's wider economy could be significant ${ }^{64}$.

\section{2.b Sectoral and socioeconomic impacts of physical climate risks}

\section{2.b.i Economic sectors listed in section 1.a which are most exposed/vulnerable to physical climate risks.}

Businesses in India are feeling the effects of recent droughts, which have increased prices and reduced water availability ${ }^{65}$. Thermal power plants are particularly at risk of shutdown in drought prone areas, which threatens India's energy security. For example, in 2016, a coal power plant in West Bengal (a state in eastern India) had to shut most of its power-generating capacity for 10 days due to lack of water for cooling. $40 \%$ of India's thermal power plants are in highly water-stressed areas ${ }^{66}$.

Studies have also identified climate-related risks across companies' values chains, with direct operations being the most severely affected and exposed most to acute physical risks, followed by emerging regulation, current regulations and chronic physical risks ${ }^{67}$. The downstream value chain is estimated to be most affected by market risks arising from climate change, followed by acute physical risks ${ }^{67}$. Changing consumer behaviour could critically affect a business operation with a shift in the demand for low-carbon intensive and higher energy efficiency product, regulations and standards.

\section{2.b.ii Examples of how these sectors may be impacted by climate change including any material impacts on trade flows.}

Indian suppliers reported $\$ 3.2$ billion in extra costs by 2026 from environmental risks ${ }^{68}$. Declining farm yield due to climate change will cause a shift in imports and export rates of agricultural products. Forecasts estimate that India will raise its net imports by $20 \%$ by 2050 due to harvest shortages, net exports are projected to decrease by roughly $20 \%$ by $2050^{69}$, while India's food purchasing power is projected drop by around $6 \%{ }^{70}$. The same forecasts indicate consumers will experience a $4.6 \%$ increase in food consumer prices as domestic yield levels fall and import level rise ${ }^{69,70}$. Securing international trade routes will become increasingly important as climate change impacts food security in India ${ }^{71}$.

\section{2.b.iii Demographic and ethnographic groups most at risk from climatic changes}

There lie significant challenges in recognising and responding to climate impacts among minority groups in India that greatly exacerbates their suffering ${ }^{72-74}$. In 2007 , the minority rights commissions were urging greater attention to the plight of Dalits, Muslims and Adivasis in India following unusually severe monsoon floods ${ }^{73}$. Dalits and Adivasis are especially vulnerable due to their dependence on earnings from agricultural labour (landless labourers), livestock rearing dependent on forests and other non-timber forest products ${ }^{73,75,76}$. Their spatial, social and economic 
vulnerabilities place a greater burden on their ability to adapt to the impacts of climate change. Moreover, the present institutional mechanisms in India for disaster management do not recognise caste induced vulnerabilities ${ }^{73,74,76}$.

The gender imbalances in land ownership are very acute in India with less than $14 \%$ of women being landowners, leaving them especially vulnerable to climate change impacts ${ }^{77}$. Dalit women are particularly at risk due to intersectional discrimination on the basis of gender and caste ${ }^{73,75,77}$. Similar instances of gendered climate injustice can be seen across India. For example, lower caste families, women and other marginal groups in the Himalayan villages in northwest India and Nepal are more susceptible to climate-related effects due to decline in ecosystem services impacting the livelihood of these communities ${ }^{78}$.

In the urban context, those living in slums are at most risk from increased flooding events due to climate change due to poor sanitation and drainage, especially in lowlying cities ${ }^{69}$. These groups are also at extreme risks from heatwaves due to poor quality housing. India is rapidly urbanising, and the challenges of climate action and sustainable development are particularly critical to its cities. By $2050,53 \%$ of India's population is projected to be urban by adding 416 million urban dwellers ${ }^{72,72}$. One in six urbanites are predicted to be living in slums, accommodations officially defined as 'unfit for human habitation'73,74. Between 2036 and 2060, it is estimated that India will have 57 cities with a million-plus population, out of which 33 cities are likely to experience increases in extreme rainfall and exacerbated flood risk, while 24 cities will see precipitation declines, indicating higher drought risk ${ }^{38}$. Heatwaves are already becoming frequent, which is projected to increase four-fold by 2050 and 12-fold by 2100 under $2^{\circ} \mathrm{C}$ warming ${ }^{75}$. Such extreme climatic events will intersect with existing vulnerabilities, leading to increased morbidity, the spread of vector-borne diseases, and loss of livelihood ${ }^{63}$.

Within the current policy framework, there is a further need to acknowledge and address the significant risk that climate change poses to India's vulnerable groups.

\section{2.b.iv Broader risks to sustainable development within the countryl region that arise from physical climate change}

Climate change will impact the degree to which India can meet several key United Nations Sustainable Development Goals: i) agriculture and food insecurity development ; ii) water stress and water insecurity; iii) regional conflict arising due to water scarcity; iv) rise in sea level threatening India's key urban and economic centres; v) threats to coastal biodiversity; vi) threats to ecosystem and biodiversity in heat and water stressed regions; vii) threat to public health from new pathogens; viii) collapse of trade routes and financial instability ${ }^{16,21,63}$.

\section{2.c Adaptation: Solutions \& Opportunities}

\section{2.c.i Country specific adaptation and resilience priorities against anticipated levels of climate change impacts}

Priorities for adaptation in response to the climate risks are set out at the National Action Plan for Climate Change (NAPCC) ${ }^{16}$. It emphasises the policy priority of 
maintaining high economic growth rates to raise living standards, the plan "identifies measures that promote our development objectives while also yielding co-benefits for addressing climate change effectively"12. The Action Plan identifies eight core "national missions" running through to 2017: Solar Energy; Enhanced Energy Efficiency; Sustainable Habitat; Water; Sustaining the Himalayan Eco-system; Green India; Sustainable Agriculture; and Strategic Knowledge for Climate Change ${ }^{19,29}$.

India's current adaptation priorities as per the NAPCC directives and missions are mostly in development. These projects are focused on policy formulation and integration, water, and agriculture, with a smaller number focused on coastal zones, forestry, agricultural, land and nature ${ }^{19}$. India's NAPCC progress on adaptation is illustrated in Table 1.

Table 1. India's NAPCC adaptation progress (source:13)

\begin{tabular}{|c|c|c|c|}
\hline $\begin{array}{l}\text { National mission } \\
\text { under NAPCC }\end{array}$ & Mission objective & $\begin{array}{l}\text { Implementation } \\
\text { status }\end{array}$ & $\begin{array}{l}\text { Budgetary } \\
\text { allocation (2012 - } \\
\text { 2017) }\end{array}$ \\
\hline $\begin{array}{l}\text { National Water } \\
\text { Mission (NWM) }\end{array}$ & $\begin{array}{l}\text { To conserve } \\
\text { water, minimize } \\
\text { wastage, and } \\
\text { ensure equitable } \\
\text { distribution }\end{array}$ & $\begin{array}{l}\text { Revised National } \\
\text { Water Policy } \\
(2012) . \text { Created } \\
\text { 1,082 new } \\
\text { groundwater } \\
\text { monitoring wells }\end{array}$ & US\$31.6 million \\
\hline $\begin{array}{l}\text { National Mission } \\
\text { for Sustainable } \\
\text { Agriculture }\end{array}$ & $\begin{array}{l}\text { To transform } \\
\text { agriculture into an } \\
\text { ecologically } \\
\text { sustainable, } \\
\text { climate-resilient } \\
\text { production system }\end{array}$ & $\begin{array}{l}\text { Developed } 11,000 \\
\text { ha of degraded } \\
\text { land. Brought } 1 \\
\text { million ha of land } \\
\text { under micro- } \\
\text { irrigation. Created } \\
5.4 \text { million tonnes } \\
\text { of agricultural } \\
\text { storage capacity. }\end{array}$ & US $\$ 2.1$ billion \\
\hline $\begin{array}{l}\text { National Mission } \\
\text { for Sustaining the } \\
\text { Himalayan } \\
\text { Ecosystem }\end{array}$ & $\begin{array}{l}\text { To evolve } \\
\text { management } \\
\text { measures for } \\
\text { sustaining and } \\
\text { safeguarding the } \\
\text { Himalayan glaciers } \\
\text { and mountain } \\
\text { ecosystem }\end{array}$ & $\begin{array}{l}\text { Established six } \\
\text { new centres } \\
\text { relevant to climate } \\
\text { change in existing } \\
\text { institutions in } \\
\text { Himalayan states. } \\
\text { Created an } \\
\text { observational } \\
\text { network to monitor } \\
\text { the health of the } \\
\text { Himalayan } \\
\text { ecosystem. }\end{array}$ & US $\$ 2.1$ billion \\
\hline $\begin{array}{l}\text { National Mission } \\
\text { for a Green India }\end{array}$ & $\begin{array}{l}\text { To use a } \\
\text { combination of } \\
\text { adaptation and } \\
\text { mitigation }\end{array}$ & Planning phase & US $\$ 2.1$ billion \\
\hline
\end{tabular}




\begin{tabular}{|l|l|l|l|}
\hline & $\begin{array}{l}\text { measures to } \\
\text { enhance carbon } \\
\text { sinks in } \\
\text { sustainably } \\
\text { managed forests } \\
\text { and other } \\
\text { ecosystems. }\end{array}$ & & \\
\hline $\begin{array}{l}\text { National Mission } \\
\text { on Strategic } \\
\text { Knowledge for } \\
\text { Climate Change }\end{array}$ & $\begin{array}{l}\text { To identify the } \\
\text { challenge and the } \\
\text { responses to } \\
\text { climate change } \\
\text { through research } \\
\text { and technology } \\
\text { development }\end{array}$ & $\begin{array}{l}\text { Established 12 } \\
\text { thematic } \\
\text { knowledge } \\
\text { networks. } \\
\text { Developed three } \\
\text { regional climate } \\
\text { models. Trained } \\
75 \text { high-quality } \\
\text { climate change } \\
\text { professionals. }\end{array}$ & US\$403 million \\
\hline
\end{tabular}

\section{2.c.ii Current/future solutions which have the potential to satisfy this country's adaptation needs, including transformation.}

Although adaptation planning and reporting is still at an early phase in India, the following are a range of current solutions that relate specifically to the priority areas identified in the country's second communication to UNFCCC $29,79$.

Forests: The present state of knowledge on the relationships between climate and forest ecosystems is grossly inadequate for the purpose of modelling future climate change impacts and hence for identifying robust adaptation strategies for forests and plantation systems in different agro-ecological zones of India ${ }^{79}$. Further research is therefore a priority.

Agriculture:This is a key sector in India and identification of appropriate adaptation strategies is critical to ensure its food and livelihood security.

Agriculture is the primary source of livelihood for about $49 \%$ of the country's population, contributing to $15.4 \%$ of India's GDP in $2016^{80}$. It accounts for just under $18 \%$ of its gross national emissions (334 $\mathrm{Mt} \mathrm{CO}_{2} \mathrm{e}$ ), mainly through rice cultivation, livestock production, fertiliser use and burning of crop residues (see Figure 1$)^{28}$.

Increasing atmospheric $\mathrm{CO}_{2}$ concentration lowers zinc content in $\mathrm{C} 3$ grain legumes (e.g., soybeans, wheat, rice, oats and green beans) which is estimated to impact the nutrition security of 48 million Indians by $2050^{31}$. Heat stress from the warming climate affects dairy breeds leading to a reduction in the nutritional content of milk ${ }^{34,81}$. In poultry, heat stress leads to poor meat and egg quality ${ }^{82}$.

Rice yield is estimated to be reduced by $3 \%$ to $15 \%$ with an increase in temperature by $1.5^{\circ} \mathrm{C}$ and reduction in the precipitation of $2 \mathrm{~mm}^{83}$, however, studies have also reported rising atmospheric $\mathrm{CO}_{2}$ is expected to improve rice yields ${ }^{84}$. Most farmers 
cultivating rainfed rice are smallholders whose local livelihood is most vulnerable to such climate impacts. Since 1980 , smallholder farmers increased by $\sim 77 \%$ to almost 66 million in 2010-1185. Climate change might be reducing annual agriculture income in the range of $15 \%$ to $18 \%$ and up to $20 \%$ to $25 \%$ for unirrigated areas ${ }^{86}$.
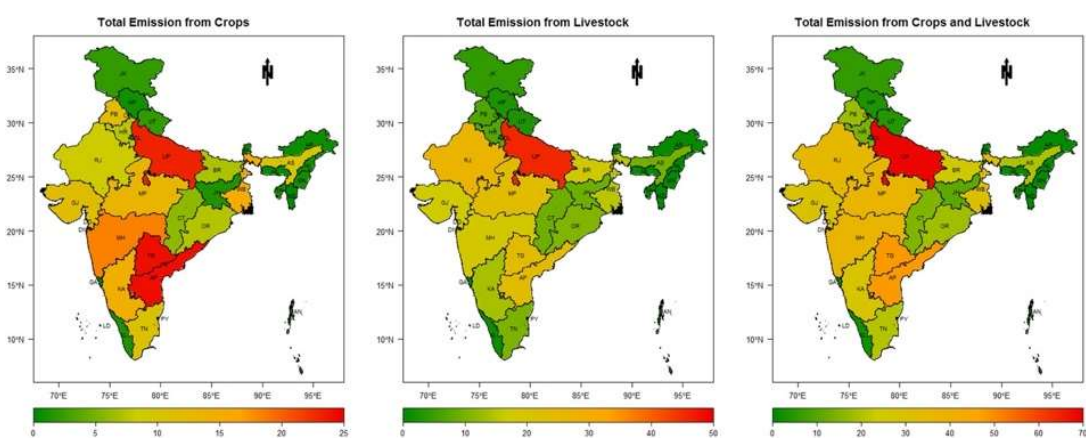

Figure 9: Total GHG emissions ( $\left.\mathrm{Mt} \mathrm{CO}_{2} \mathrm{e}\right)$ from crops, livestock and crop plus livestock combined (Source:28)

India is expected to surpass China to become the world's most populated country by 2027 , yet its landmass accounts for only $2.4 \%$ of the global land. The average size of landholding per state is 1.08 hectares, according to the Agricultural Census 2015-16 ${ }^{87}$.Smallholder farmers are especially vulnerable to climate change as it directly or indirectly influences the water availability, intensity and frequencies of drought and soil quality ${ }^{88}$. Studies have shown that climate warming reduced wheat yields by $5.2 \%$ from 1981 to 2009, despite adaptation measures ${ }^{83,89}$. Considerable resources are needed to research conservation architecture (efficient use of resource), change in crop management and crop diversification. Adaptation strategies and opportunities also include adjusting cropping season, early warning systems and crop insurance, water and watershed management.

Augmenting production and income for future climatic stress conditions is also envisioned as an adaptation solution. Harvest and post-harvest management can be carried out for minimizing the losses due to extreme climatic events or mean climate change conditions. Farmers in South Asia, often poor and marginal, have been adapting to climatic variability using vernacular techniques for a long time. For example, traditional organic composting in the Himalayan villages enhances the soil's organic matter which subsequently leads to increase carbon sequestration. Similarly, rice-fish culture is a 1500-year old practice in India that reduces fertilizer dependencies. There is a wealth of indigenous knowledge for a range of measures that can help in developing technologies to overcome climate vulnerabilities.

Livestock: The livestock sector is one of the significant contributors to GHG emissions in India. Livestock species of India are well-adapted breeds, and prospects for these animal species to adapt to increased air temperature through traditional breeding and genetic modifications appear to be promising. Livestock management and proper housing under tropical conditions will help in abating extreme productivity losses. The livestock producer awareness of livestock thresholds for physiological stress can help in the adaptation of livestock to climate change and reduce losses due to temperature variability and rise due to climate change ${ }^{79}$. 
The six critical priority areas of the Indian adaptation planning process are as follows: i) Economic security; ii) Energy security; iii) Environmental security; iv) Water security; v) Food security; vi) Provision of shelter and health for all.

The sector of focus for current adaptation projects and programs identified in India are illustrated in Figure 7.

\begin{tabular}{|c|c|c|c|c|c|}
\hline Sector of focus & $\begin{array}{l}\text { India's priority } \\
\text { sectors for } \\
\text { adaptation }\end{array}$ & $\begin{array}{l}\text { Number } \\
\text { of } \\
\text { projects }\end{array}$ & $\begin{array}{l}\text { Percentage } \\
\text { of total } \\
\text { projects }^{b}\end{array}$ & Geographical scale & \\
\hline Agriculture & $\checkmark$ & 9 & $30 \%$ & National projects & 15 \\
\hline Forestry & $\checkmark$ & 1 & $3 \%$ & Regional projects & 10 \\
\hline Freshwater fisheries & $\checkmark$ & 2 & $7 \%$ & Global projects & 5 \\
\hline Freshwater supply & $\checkmark$ & 5 & $17 \%$ & Total & 30 \\
\hline $\begin{array}{l}\text { Watershed } \\
\text { management }\end{array}$ & $\checkmark$ & 5 & $17 \%$ & & \\
\hline $\begin{array}{l}\text { Coastal zone } \\
\text { management }\end{array}$ & $\checkmark$ & 3 & $10 \%$ & & \\
\hline $\begin{array}{l}\text { Ecosystem } \\
\text { conservation }\end{array}$ & & 3 & $10 \%$ & & \\
\hline $\begin{array}{l}\text { Disaster risk } \\
\text { management }\end{array}$ & $\checkmark$ & 7 & $23 \%$ & & \\
\hline Gender & & 2 & $7 \%$ & & \\
\hline Insurance & & 2 & $7 \%$ & & \\
\hline Energy & $\checkmark$ & 1 & $3 \%$ & & \\
\hline Urban areas & $\checkmark$ & 4 & $13 \%$ & & \\
\hline Human health & $\checkmark$ & 1 & $3 \%$ & & \\
\hline Climate information & $\checkmark$ & 4 & $13 \%$ & & \\
\hline Government & & 10 & $33 \%$ & & \\
\hline Civil society & & 3 & $10 \%$ & & \\
\hline Multisectoral & & 3 & $10 \%$ & & \\
\hline Other & & 4 & $13 \%$ & & \\
\hline \multicolumn{6}{|c|}{$\begin{array}{l}\text { - Individual projects may address one or more sectors. } \\
\text { ' Calculated by the number of projects active in this sector relative to the total number of projects identified, } \\
\text { reflecting the potential for a single project to be addressing adaptation needs in more than one sector. } \\
\text { 'For each of the following categories, one project was identified as addressing needs pertaining to the sector: } \\
\text { biodiversity protection, migration, transportation, and social protection. }\end{array}$} \\
\hline
\end{tabular}

Figure 7: Current adaptation projects and programs supported through both aid and government spending identified in India ${ }^{13}$ 


\section{2.c.iii Locally specific emerging sectors that might be of future importance for adaptation}

India has long put a key emphasis on the need for climate finance and technology transfer from developed to developing countries. As India faces complex developmental challenges, the need and availability of international financing and technology transfer will be critical in the adaptation and emission reduction efforts ${ }^{90}$. It will cost at least $\$ 2.5$ trillion to implement its climate pledge. Although, India received the highest level of single-country climate funding between 2013 - 2016, its per-capita funding was relatively low at just $\$ 0.56 /$ person $^{91}$.

\section{Development compatible transition - risks, mitigation and opportunities}

\section{3.a. Socioeconomic and sustainable development risks of a net zero transition}

\section{3.a.i How different demographic and ethnographic groups would be impacted by a net zero transition}

The impact of a net zero transition will not be felt equally across India's demographics. For example, the transition away from coal production would result in the loss of coal sector jobs, with coal mining supporting many communities across eastern and southeastern India. A transition to net zero should recognise 'stranded workers' and communities, alongside any other assets proving them with social and financial protection $^{92}$.

However, a transition away from coal will also have significant positive impacts on many Indian communities. Mining in India has displaced many communities who once lived in coal-rich areas. It is estimated that between 1950 and 1990, 2.5 million Indians were displaced from their homes as the coal sector grew ${ }^{93}$. Renewable energy presents an opportunity for a more equitable and less disruptive form of energy production ${ }^{94}$.

Indeed, a move away from coal could create opportunities for vulnerable communities in India. For example, the rise in decentralised energy provision, especially microrenewables, could create significant job opportunities for women in India. Jobs will emerge as new value chains are established, including installation, service, appliance, operations and maintenance ${ }^{95}$. In India women already hold $60 \%$ of the informal jobs in the decentralised energy provision sector ${ }^{95}$. There is a need, however, to ensure that these new opportunities are positive rather than exploitative, with concerns of consistency of income and health care addressed.

Policy decisions and sector adaptations need to be based on informed research. Understanding of the impact of net zero transitions on India's complex demographic landscape is lacking ${ }^{96}$. Such research is vital to ensure that the benefits of a net zero transition are felt across India's society and that any potential negative impacts are mitigated.

3.a.ii Risks to broader sustainable development within the country/region that could arise 
There is an argument that India is in no position to set an economy-wide net-zero target if it wants to sustain economic growth, pull millions out of poverty and provide power to the millions still underserved. They argue that at best it can aim for net-zero emissions in select sectors such as power and transport, in which it has access to effective technological solutions ${ }^{97}$. For example, if India chooses a faster transition towards low-carbon growth in the electricity generation sector, it will affect the revenues of the coal-dependent states. This could render half a million people jobless and lead to higher railway passenger fares due to the cross-subsidy mechanism ${ }^{98,99}$.

However, as stated above, the relationship between coal and sustainable development in India is far from linear. India has some of the worst air pollution in the world. Coal production forms a substantial proportion of this pollution with over 75,000 premature deaths a year due to coal-linked emissions ${ }^{100}$. Particulate matter generated by coal-fired power plants also has a significant impact on respiratory diseases. A 2021 study demonstrated a link between upper respiratory tract infection and those residing near the coal-fired thermal power plants in central India ${ }^{101}$.

Although coal-fired power stations are often built in poorer rural areas, many of these areas still do not have wide-spread electrification ${ }^{94}$. A quarter of these power-plants are also found in 'red-listed' sites where ground water is at danger of drying up due to intensive extraction by the coal industry. Ground water is vital for the survival of poor rural farming communities in these regions ${ }^{94}$.

A 2014 study also concluded that air pollution could be having a significant impact on India's crop yields, further compounding the impact of coal production on India's food security ${ }^{102}$.

Limited land availability is a tremendous challenge. Land is needed to feed the growing population, to support livestock, to protect and preserve forests both from a carbon sink perspective and to support livelihood and biodiversity, and to support an energy transition ${ }^{103}$.

India's structural inequality will also compound the risks of climate change for many vulnerable communities. For example, a 2014 study in northwest India illustrated that social status was a key determinant of adaptive capacity to climate change ${ }^{78}$. Another 2019 study carried out in the state of Sikki observed that women stand to be highly vulnerable to the impacts of climate change, with issues of income and water access being particularly important in elevating risk ${ }^{104}$.

\section{3.b Just Transition}

\section{3.b.i What are the priorities for enabling a just transition in this country?}

There are several key priorities for enabling a just transition in India. Firstly, given their contribution to $\mathrm{CHG}$ emissions and impacts on public health, there should be a transition away from coal-fired power plants and a decarbonisation of the transport sector. Agriculture is one of India's most important sectors and any transition to net zero must see it as a policy priority. Climate-smart agriculture should be adopted to reduce $\mathrm{CHG}$ emissions and foster resilience and adaptation strategies amongst India's farming communities 
To further India's development goals, it is also important that all Indian's have access to reliable, clean energy to further employment, education and health prospects and reduce poverty levels. The benefits and risk of a net-zero transition should be distributed evenly across society, with vulnerable and socially excluded groups included in net zero pathways.

\section{3.b.ii What are some examples of future opportunities that could enable a just transition in this country, including adaptation to transition risks?}

India needs to target specific sectors to enable a just transition where a reduction in carbon emissions is paralleled with strong economic growth. This dualism makes lowcarbon transition of Indian economy extremely complex 5 .

The electricity sector emissions are predicted to peak within the next 15 years, giving room within national climate targets to keep emission margins for carbon-intensive sectors like industry, aviation and freight ${ }^{103}$. With renewables now accounting for nearly a quarter of the country's total installed power generation capacity, it is converging towards grid-parity with coal-based generation. Rooftop solar has tremendous potential as land is always scarce for large-scale solar power plants, but it remains largely untapped. There need to be incentives for rooftop solar and there is a need to create awareness among the public about its financial benefits ${ }^{97}$. The political economy of decarbonising electricity is India's biggest hurdle as cheap electricity for residential consumers is based on a cross-subsidy mechanism that operates through industrial and commercial tariffs. It remains an electoral issue, with debt-ridden electricity distribution companies believing renewables will disrupt their business ${ }^{97}$.Just transition in the transportation sector must improve its cars' energy efficiency and move to phase out from fossil fuel dependency. India being in the early stages of planning its transportation infrastructure has the opportunity to lock in green pathways, however, until there is a transition from coal to renewables, electrical vehicles cannot contribute effectively to the net-zero efforts. Decarbonising transport will need innovative policy support, that remains missing in the current net-zero transition space of India97,105. For example, government's 'Go Electric' Campaign is an important initiative to spread awareness on the benefits of e-mobility and EV Charging Infrastructure as well as electric cooking in India. It would help in reducing the import dependence of India in the coming years ${ }^{106}$.

Decarbonising India's manufacturing sector will be tough even though the modern steel and cement industry are highly energy efficient. Just transition in this regard would need rethinking energy policies as industries tend to shift to captive power generation using fossil fuels, instead of paying high tariff rates for grid connection. It is based on a cross-subsidy mechanism that charges commercial consumers a significantly higher tariff for lower residential charges ${ }^{97,107 .}$

\section{3.c Sectoral and socioeconomic impacts of a development compatible transition under each of the following transition pathways}

\section{- Steady, orderly, persistent transition pathway}

No evidence was found for India from governmental institution/agencies on proposed transition pathways. There are projections for steady, orderly, persistent transition 
pathway for net-zero energy systems by the private sector (Shell and TERI) ${ }^{108}$. The areas of action for next 30 years for achieving net-zero need to be in accelerating clean technologies, supporting energy-efficient and lower-carbon choices and developing carbon removal approaches to address unavoidable emissions (see Figure $8)^{108}$.

\section{Decline in energy emissions for most sectors}

\section{Remaining emissions are removed using technology and nature}

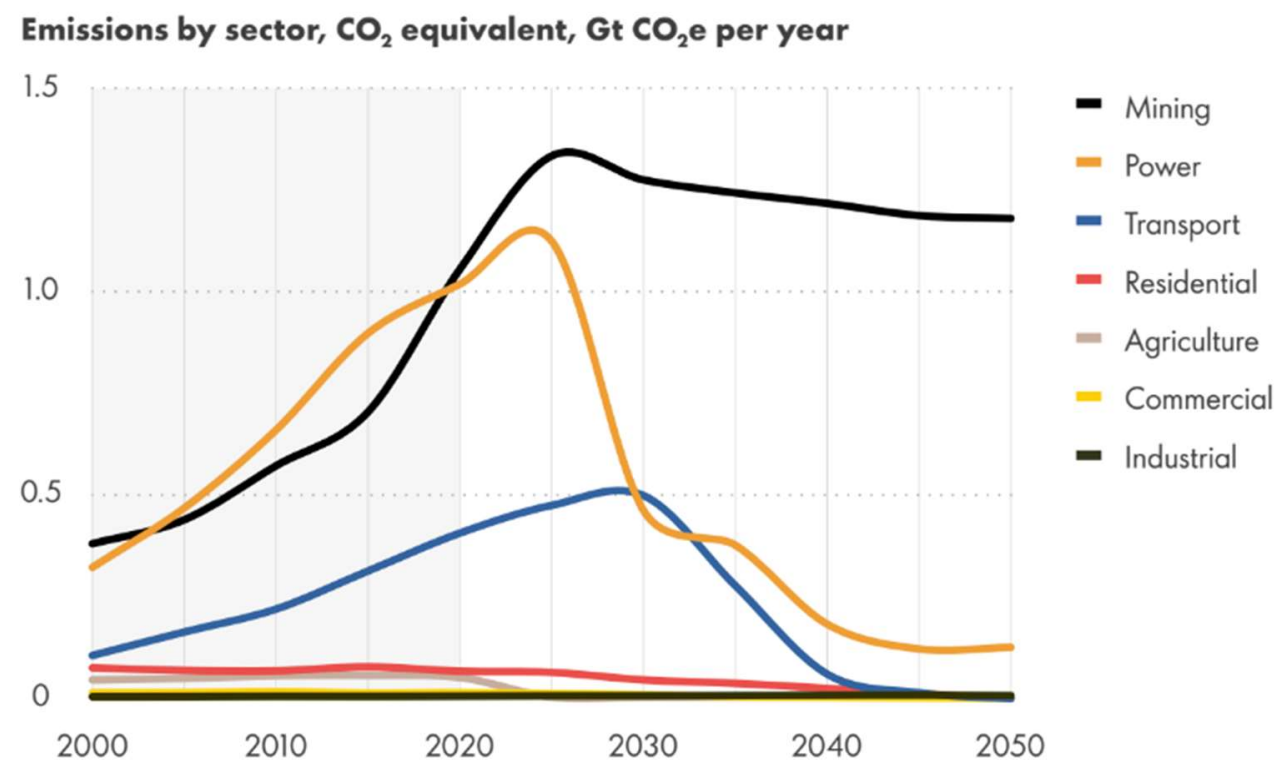

Figure 8: 3 Decline in emissions for most sectors based on Shell and TERI net-zero actions (source: ${ }^{108}$ )

\section{- Late, disorderly transition pathway}

In general, a late and disorderly transition will affect all stakeholders and further deviate India from its climate goals. However, as mentioned in the NAPCC, mitigation and adaption in a country like India is extremely complex and achieving net-zero across the economy is even tougher ${ }^{108}$. The most plausible action is to cut emissions on a sector basis to enable a just transition to net-zero ${ }^{97}$.

\section{Sectoral Impacts}

These sectors were identified as priority sectors of key importance for a transition to a resilient, inclusive and just net zero future in India, in consultation with the India expert committee members. Priority sectors are: i) Agriculture; ii) Buildings; iii) Electricity generation; iv) Nature-based Solutions (NbS); and v) Surface transport. 
Including:

3.c.i Sectors most likely to be impacted, including material impacts on tradeflows, and considering both risks and opportunities.

3.c.ii Examples of how these sectors may be impacted by a net zero transition, including any material impacts on trade flows.

\section{3.d Development compatible emissions: Solutions \& Opportunities}

3.d.i Current/future solutions that can enable development-compatible emissions reduction in this country (in line with the SDGs).

3.d.ii Locally specific emerging sectors that might be of future importance for development compatible mitigation.

3.e Likely co-benefits and trade-offs of the solutions and opportunities identified, including, where relevant, in the context of the Sustainable Development Goals

\section{Agriculture}

Climate change poses a threat to India's food security with frequent dry spells, heat waves and erratic monsoonal rainfall, adding to farming insecurity and impacting their ability to feed an increasing population $28,80,109$.

Farmers in half of the Indian states are marginal (with land less than 1 hectare(ha)); the remaining are small farms (landholdings of 1-2 ha) ${ }^{80}$. Indeed, farmers are one of the most precarious communities, with income often not enough to meet their daily needs ${ }^{30,80}$. Smallholder farmers are less literate, often marginalised and are generally excluded from modern market arrangements such as contract farming or direct purchase $^{30,110,111}$

Indian farmers need good land, healthy soils, adequate and good quality water, easy credit availability (at a low-interest rate), access to national and global markets, and the respect and dignity they deserve in society ${ }^{80,111}$. A sustainable supply chain needs to be established to warrant timely supply of critical inputs and technologies that can ensure higher and efficient production ${ }^{111,112}$. Improving the supply chain is critical for lowering the disruption of price signals and reducing post-harvest losses ${ }^{112}$. Three key opportunities lie in capital investment and Conservation Agriculture (CA) and carbon sinks:

- Capital investment: India is in urgent need of policy reforms to capital investment in agriculture (both public and private), especially in the eastern, North-eastern, dryland and coastal regions that are capable of more sustainable Green Revolutions in the future. Credit access to the farmers and young entrepreneurs at low interest rate should be increased alongside the creation of more financial institutions, and marketing infrastructure $80,113,114$. New 
prospects could be created by harnessing science with precision agriculture, biotechnology, bioinformatics, sensor technology, robotics, drones, big data management, artificial intelligence and climate-smart agriculture ${ }^{115-117}$. For example, biofortification is envisaged as a powerful tool for sustaining nutrient security. In 2018, the Indian Council of Agricultural Research established minimum levels of iron and zinc to be bred in national varieties of pearl millet, providing a strong regulatory push for the development biofortified varieties of pearl millet. However, there is an urgent need to eliminate policy bias, create public awareness around their nutritional benefits, make provision of premium biofortified crop varieties ${ }^{80,118}$. Policies need to recognise that the consequence of aggravating climate impacts like drought and flood fall hardest on the marginal farmers who are most vulnerable to their effects $30,119,120$.

- Conservation Agriculture: CA is an embodiment of climate-smart agriculture in India ${ }^{121}$. It has proven credentials in mitigating the consequences of global warming by sequestering soil organic carbon, lowering chances of soil temperatures to rise, and sustaining necessary productivity growth by making agriculture more efficient, competitive and a resilient enterprise in the country 121,122. The Gol proposes developing a system of innovation involving partnership among farmers, agricultural scientists, development department officials and private individual/ firms to extend CA as an adaptation strategy 80,122 . The climate change mitigation value of CA would be further enhanced by moderating the ongoing rise in the consumption of animal-based foods ${ }^{80}$. Awareness needs to be created by educating people on the negative consequences of producing and consuming animal-based foods on climate change ${ }^{80}$. It is estimated that GHG emission from the agricultural and livestock sector could be reduced by up to $9 \%$ from 2012 levels through efficient use of fertilisers, adoption of zero-tillage and management of water used in rice irrigation. However, these measures must be supplemented by better subsidy schemes for fertilisers, energy and water, and the replacement of subsidy investments for payment for efficient use and consequent generation of environmental services ${ }^{28,80,121}$.

- Carbon sinks: India's long-term climate change mitigation strategy in the agriculture sector focuses on plans that create a lasting sink for $\mathrm{CO}_{2}$ and minimize emissions ${ }^{30,30,32}$. Greening soil cover is critical for turning soil into a carbon sink by restoring the lost forest cover (reforestation) and forestation of denuded and barren lands (afforestation) ${ }^{35}$, disallowing shift of ecologically productive lands to other uses, introducing land-use plans that maximise land cover period through agroforestry and, inducting conservation agriculture for the cultivation of crops that is coherent with the land attributes and the market $35,80,123$.

Short-term mitigation measures build a foundation around innovative practices, technologies, or services, which help improve adaptive capacity, enhance food security, and reduce environmental footprints of food production. These are the building blocks of India's climate-smart agriculture strategy ${ }^{124,125}$. In the medium-term, the Indian government (Gol) stresses increasing reliance on renewable energy sources in the farming sector ${ }^{80,107}$. It envisages rapid technology diffusion of solar pumps and solar home systems through the $100 \mathrm{GW}$ solar energy target by $2022^{107}$. 
Likely co-benefits are fulfilment of SDG-2 (zero hunger) through food and nutrition security from conservation agriculture. It can also contribute to the national goals associated with SDG-12 (responsible consumption and production) while promoting decent work and economic growth (SDG - 8).

\section{Buildings}

A major expansion of construction is expected over the coming decades. The new construction activity will be concentrated in urban areas, making urbanisation a key driver for energy-intensive material demand. For example, the demand for cement and steel is set to double by $2040^{2}$. By 2040 , the building floor space area in India is expected to grow by $150 \%$ to 50 billion square metres from 20 billion square metres in $2020^{9,126}$. The construction boom is further fuelled by a renewed focus on public housing for low-income communities with the overarching goal of "housing for all" by $2022^{9,127}$. With more than 150 million Indians living in informal settlements or slums with a lack of basic infrastructure and services, public housing programs aim to provide a house built with modern building materials and rehabilitate slum dwellers to permanent building structures ${ }^{127,128}$.

With rising temperatures, air conditioners $(A C)$ are also set to emerge as the single most significant source of electricity demand in the Indian building sector ${ }^{9,129}$. Its ownership is driven by frequent hot and humid weather conditions in large parts of India. These conditions are being made more acute by climate change, growing building stock and rapid urbanisation leading to urban heat island effects ${ }^{130}$. At present, new construction and AC have contributed to a $500 \%$ increase in electricity demand since $2010^{131,132}$. International Energy Agency (IEA) predict AC stock to reach 670 million in 2040, up from 30 million today ${ }^{129}$. By 2030, ACs are anticipated to contribute around $30 \%$ of national peak demand, approximately 140 gigawatts $(\mathrm{GW})^{129,133}$. It mainly concerns low-income communities, as climate change-led rise in energy demand will compel them to purchase air conditioners that will drive higher electricity bills and expand existing poverty traps ${ }^{134,135}$.

India's building sector offers a GHG mitigation potential of 0.3 gigaton (Gt) of $\mathrm{CO}_{2}$ equivalent by 2050 , equating to about $8 \%$ of the total global GHG mitigation potential of the building sector ${ }^{61,126}$. Nonetheless, $90 \%$ of this mitigation potential corresponds to the new building stock, while retrofitting existing buildings offers just under $10 \%$ of total energy savings potential ${ }^{136}$. Building energy consumption in India represents $14 \%$ of total delivered energy. About $70 \%$ of the growth in building energy demand in India is driven by the residential sector, which currently is not covered by mandatory building energy performance regulations ${ }^{107,131}$. In the current paradigm, the residential electricity consumption could increase by $700 \%$ in 2030, compared to 2010 levels ${ }^{137,138}$.

Low-carbon technology transfer in the building sector in India could be created around a need-driven approach built on a collaborative and ongoing local assessment process driven by developed and developing countries ${ }^{138,139}$. It will require the technologies to adapt to local contexts and operating conditions, like green building design evolved around vernacular and passive architecture and occupant use pattern ${ }^{140}$ or policy 
delivery models that consider behavioural norms or financial realities of consumers ${ }^{138}$. Adaptive capacity building of low-carbon technologies is critical for transitioning to a below $2^{\circ} \mathrm{C}$ pathway for the building sector in India ${ }^{132,138}$. Capacity building for skills is needed for the operation of low-carbon technologies, including design-based building energy efficiency certifications ${ }^{132}$. The ability to test and verify building energy performance following international standards is also essential to progressively increase minimum energy performance standards in building codes and energy certification programmes ${ }^{141}$.

Encouraging energy-conserving behaviours and consumer choices is critical for adopting high-efficiency and low-carbon technologies to achieve low- or net-zero energy performance ${ }^{142}$. The IPCC states energy-conserving behaviour by building inhabitants could deliver between $20 \%$ and $40 \%$ energy savings compared with business as usual ${ }^{143}$. In addition, integrating 'smart' technologies into buildings can deliver significant energy savings by making energy-conserving behaviour easier, more enjoyable and, where required, autonomous ${ }^{132}$. Greater emphasis is needed on using digitisation and smart technologies to decarbonise the ever-growing building sector in India.

The growth in cooling demand could be mitigated by energy efficiency improvements in ACs as well as thermally efficient building design. India has the potential to deliver about $30 \%$ of $\mathrm{CO}_{2}$ emission reduction by 2050 through high efficiency space cooling ${ }^{129}$. The Indian government launched the India Cooling Action Plan in 2019 to reduce cooling requirement by $25-40 \%$ by $2037-38^{144}$ by adopting a principle of "thermal comfort for all', including low-income groups. However, the precise nature of this commitment is not defined ${ }^{107,135}$. The IEA estimates that robust implementation of energy efficiency policies can offset the addition of 130 million ACs in 2040 through efficiency gains ${ }^{107}$. Effective implementation of the Energy Conservation Building Codes (ECBC) for commercial buildings and the Eco-Niwas Samhita for residential buildings could reduce the cooling demand by $15-20 \%{ }^{132}$. Non-state actors in India like companies, cities, subnational jurisdictions, investors and civil society organizations are set to play a significant role in emission reduction in the building sector (see Figure 10) ${ }^{132,145}$.

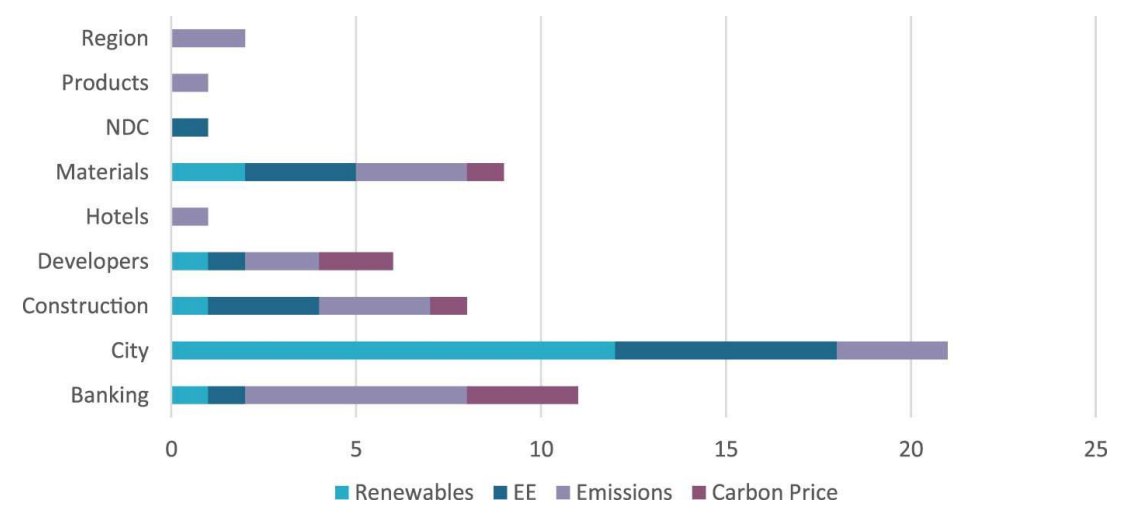

Figure 4. Commitment types in percentage in the building sector by Indian non-state actors (Source: ${ }^{145}$ )

In India, an unprecedented shift to LED lights - which use $75 \%$ less energy, also shows the importance for developing nations to rapidly and cheaply lock in low-carbon 
technologies through public policy innovation ${ }^{107,131}$. Between 2014 and 2018, the market share of LED lamps grew from $0.3 \%$ to $46 \%$, resulting in 30 terawatt-hours (TWh) of annual energy savings - roughly enough to power 28 million average Indian households for a year ${ }^{146}$.

A net-zero transition in the building sector can offer a wide range of co-benefits from improving energy efficiency in the built environment (SDG - 11) to large-scale renewable integration (SDG - 7). In this process, opportunities will emerge for work and economic growth (SDG - 8), industry, innovation and infrastructure (SDG -9). Energy efficiency at the residential level also presents opportunities for cleaner transition in cooking energy. Electric and improved biomass cookstoves in India can make households healthier, improve local environments, and reduce pollutants (SDG - 3) that cause climate change ${ }^{147}$. While large-scale dissemination remains a challenge for India, greater adoption opportunities can be created by embedded local cultural contexts and nurturing localised supply chains through entrepreneurship ${ }^{147}$.

\section{Electricity generation}

\section{Share of electricity production by source, India}
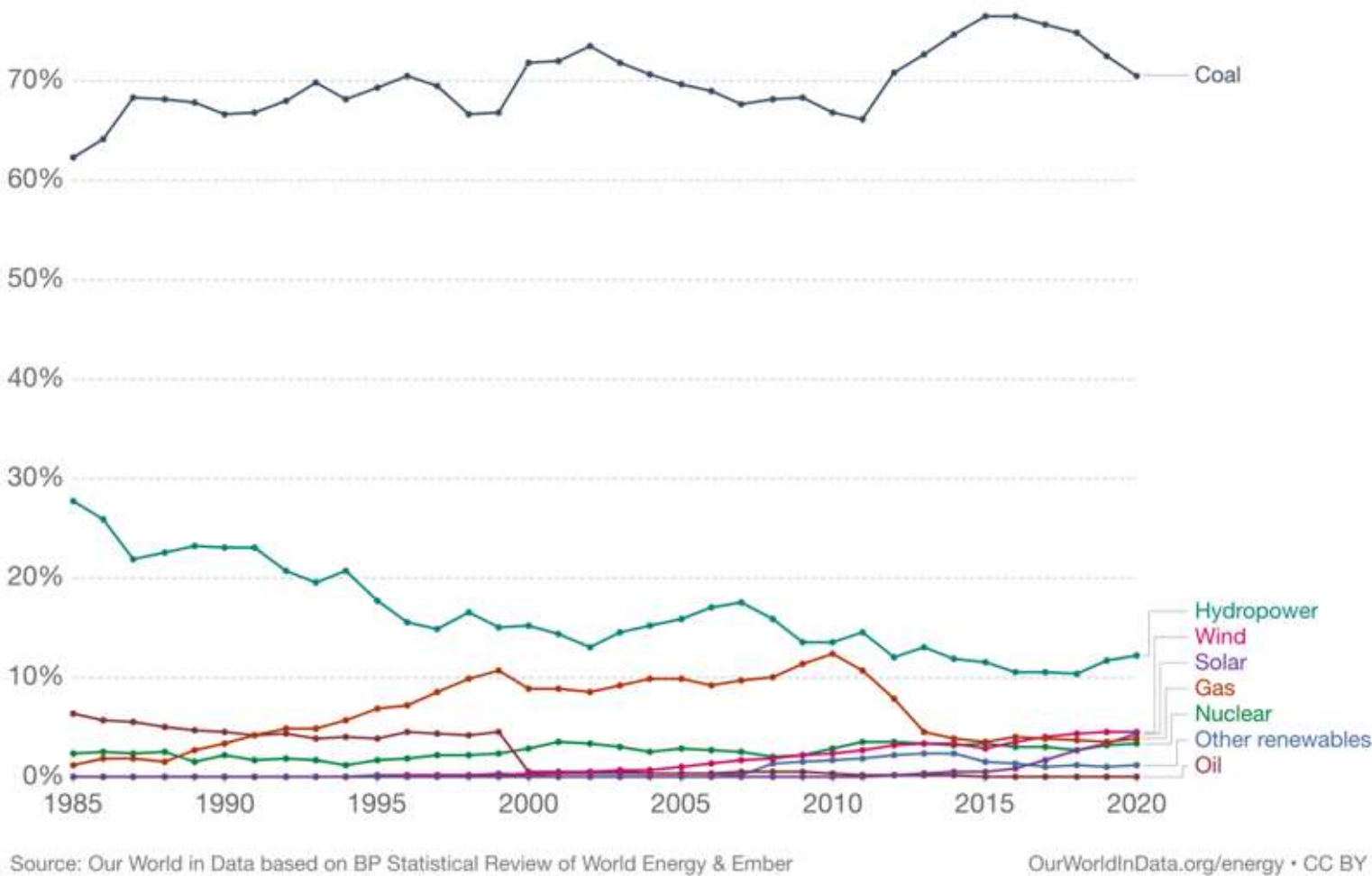

Figure 11: India's electricity generation mix (source:148)

India is the world's third-largest energy-consuming country ${ }^{9}$. Energy use has doubled since 2000 , with $80 \%$ of India's energy needs being met by three fuels: coal, oil and solid biomass. In 2019, $97.8 \%$ of Indian households were connected to the grid, with another $0.33 \%$ relying on off-grid electricity sources. The per capita electricity 
consumption rose to $1208 \mathrm{kWh}$ in 2013 from $914 \mathrm{kWh}$ in 2012, an increase of $32 \%{ }^{149}$. Coal has fuelled the rapid growth in Indian electricity use, and its coal fleet has more than tripled in size since 2000, making it the second-largest coal consumer in the world $^{90}$. In 2017 , coal generated $76 \%$ of India's electricity (see Figure 11 ) ${ }^{9}$.

India is the third-largest global emitter of $\mathrm{CO}_{2}$ (2.4 Gt in 2018, see Figure 1), despite a low per capita $\mathrm{CO}_{2}$ emissions ${ }^{9,90}$. Figure 5 shows electricity/heat was the largest contributor to carbon emissions, amounting to $1.24 \mathrm{Gt}$ in 2018 . The carbon intensity of its electricity generation $(0.28 \mathrm{~kg} / \mathrm{kWh}$ in 2016$)$ is well above the global average, especially above Brazil, Kenya, Jamaica, Saudi Arabia, UAE and the UK ${ }^{9}$ (see Figure 12).

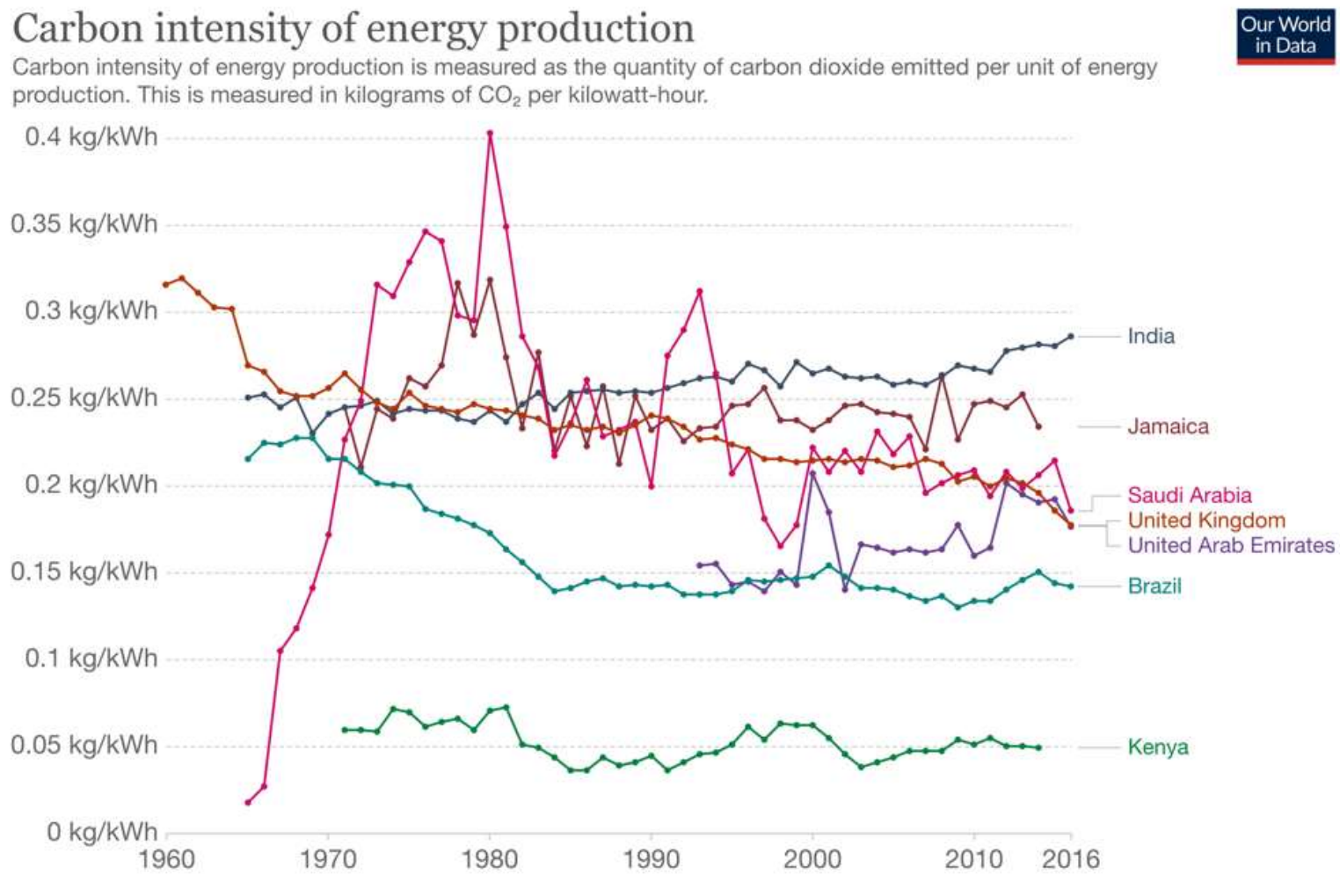

Figure 12: 5. India's carbon intensity of energy production (Source:148)

The share of non-fossil-fuel-based electricity generation in total installed capacity reached approximately $38.18 \%$ in November 2020 . There has been an increasing focus on the use of renewables in power generation, which is further aided by enabling government policies, together with regulatory support, at both the Centre and the States. The power generation capacity share of renewables grew from $4.98 \%$ as of March 2006 to $23.92 \%$ by September $2020^{1}$.

India set an ambitious renewable energy target of $450 \mathrm{GW}$ by 2030 , as per its NDCs. The current target aims at a six-fold expansion of renewable energy generation to 100 GW of solar energy capacity and $20 \mathrm{GW}$ of wind energy capacity by $2022^{99,150}$. However, the country needs to restore the health of its ageing power system through digitisation, decarbonisation and decentralisation of the grid $^{96,99}$. 
Demand side management was only given attention in the $1990 \mathrm{~s}^{144}$. The Energy Conservation Act came into existence in 2001, with the objective of conservation and the efficient use of energy. The adoption of energy efficiency schemes/ programmes has led to the overall energy savings of 23.728 Mtoe for the year 2018-19. After the success of the first Perform, Achieve and Trade (PAT I) cycle (2012-13 to 2014-15), which resulted in total energy savings of 8.67 Mtoe, and emission reduction of 31 $\mathrm{MtCO}_{2}$, PAT II was rolled out. The PAT II cycle (2016-17 to 2018-19) resulted in total savings of approximately 13.28 Mtoe savings, translating into $61.34 \mathrm{MtCO}_{2}$. In addition, energy efficiency initiatives in the micro, small and medium enterprises (MSME) sector led to a total emission reduction of $0.124 \mathrm{MtCO}_{2}$ in 2018-191.

An aggressive shift to renewable energy for India's currently coal-dependent economy would have a significant impact. Limited studies have shown long-lasting effects of rapid retirement of coal power plants on the country's political economy, leading to social unrest $99,151,152$. Coal industries, directly and indirectly, impact close to 10-15 million livelihoods in India, the shutdown of coal power plants will put severe stress on the social security of coal-rich states ${ }^{62}$. It will also affect central government financing that will affect investment in modernisation efforts of the power system. In addition, the railway economy will be severely impacted because it is built around a crosssubsidisation mechanism between coal freight and passenger freight ${ }^{152}$. Passenger fares will increase at a political cost, which may reduce investment in renewable and low carbon technologies ${ }^{153}$. There is a need for India to manufacture renewable energy technologies indigenously to reduce import dependencies in accelerated clean energy scenarios to secure national security ${ }^{99}$. A net-zero future of the electricity generation sector should account for such social dimensions of the low-carbon transition.

(3.d.i) With accelerated renewable generation in the grid, India requires a massive increase in power system flexibility ${ }^{7}$. Currently, the country's large grid and coal fleet meet the bulk of its flexibility needs in the short term, supported by hydropower and gas-fired capacity ${ }^{9,96}$. However, in the long term, new power lines and demand-side options will be critical in meeting the flexibility needs driven by the rising shares of solar PV and wind power and variable load patterns from electric vehicles and higher cooling demand ${ }^{9,96}$. Strategies like improving the energy efficiency of air conditioners in the residential sector, lock-in of low carbon technologies, shifting the operation of agricultural pumps to different parts of the day or intelligent charging of electric vehicles will play an essential role in enabling flexible operation of the national $\operatorname{grid}^{96,99,154}$.

Battery storage is particularly critical in short-run flexibility to align India's solar-led generation peak in the middle of the day with the country's evening peak in demand. The IEA estimates $140 \mathrm{GW}$ of battery capacity in its stated policy scenario, while 200 $\mathrm{GW}$ in its sustainable development scenario for $2040^{\circ}$. Hydrogen, hydro generation, interconnections and fast-acting thermal generators can be major flexibility options in the long term. However, it will require aggressive policy interventions, regulatory mechanisms and market designs.

In 2010, the total installed solar capacity was $10 \mathrm{MW}$ that increased to $30 \mathrm{GW}$ in 2019. India became the lowest-cost producer of solar power in 2018. This was a success story of a public-private partnership model. It involved an active role of central and state governments, incentives and policies (like the Jawaharlal Nehru National Solar 
Mission (JNNSM) since 2010, certainty from streamlining of land acquisition, low cost of labour, and price sensitivity of Indian solar market ${ }^{155}$.

The flaring from natural gas also contributes significantly to India's GHG emissions (see Figure 1), yet at present, no solutions have been explored. Two important stateowned oil and natural gas companies, ONGC and Oil India Limited endorsed the Global Gas Flaring Reduction Partnership (GGFR) by the World Bank to support just transition. India is yet to form actionable objectives for GGFR.

Energy transition from fossil-fuel to renewable sources is critical for India's net-zero vision. However, such transition needs to systematically evaluate the trade-offs of accelerated retirement of coal-based electricity generation. Huge opportunity lies in the growing renewable markets, low-carbon technologies and manufacturing capacities (SDG - 9). There are also opportunities for development of niche business models that embeds local contexts for accelerated renewable adaptation.

\section{Nature-based Solutions (NbS)}

Nature-based solutions ( $\mathrm{NbS}$ ) is an overarching term for several nature-based approaches like Ecosystem-based Adaptation (EbA), Natural Climate Solutions (NCS) and eco-Disaster Risk Reduction (eco-DRR). NbS is critical for mitigating socioeconomic losses of climate change and building systemic resilience ${ }^{143,156}$.

India aims to increase its carbon sink from 2.5 to 3 billion tonnes $\mathrm{CO}_{2}$ equivalent by increasing forest cover (primarily through agroforestry) ${ }^{156}$. These actions help address societal challenges and foster development by working with nature and anchoring solutions with local communities ${ }^{157}$. For example, the Global Commission for Adaptation ${ }^{158}$ notes that the cost-to-benefit ratio of preserving mangroves is up to 1:10 in terms of avoided losses from coastal flooding and non-market benefits associated with fisheries, forestry and recreation ${ }^{158,159}$.

Studies have shown NbS as effective adaptation strategies for Indian cities to face the climate risks ${ }^{143,157,160,161}$. Several case-based examples from initiatives such as Asian Cities Climate Change Resilience Network (ACCCRN), 100 Resilient Cities Program, and sectoral assessments such as on sustainable water and disaster risk management ${ }^{157,162}$. The ACCRN designed better management of natural water bodies and prevented construction on the floodplains in western India ${ }^{163}$. Similar practices were adopted in central India with the help of the Indian government and community participation to conserve and manage traditional water sources ${ }^{162,164}$. In eastern India, wetlands have been utilised for years to clean the city's wastewater ${ }^{165}$. These wetlands provide livelihood opportunities to 50,000 people through pisciculture and agriculture ${ }^{165}$. Recent examples from Southern India shows the large-scale promotion of NbS-based activities like zero-budget natural farming, which relies entirely on using organic inputsto improve the resilience of both crops and land ${ }^{166}$.

One of the globally recognised success stories is from the western state of Rajasthan, where an NGO used the NbS approach to support local communities led by women to revive local water bodies to help fight one of the worst droughts in the state, increased productive cropland replenished forest cover by around $33 \%{ }^{162,167}$. It was led by the NGO Tarun Bharat Sangh that supported local women to rejuvenate regional water 
bodies to help fight one of the worst droughts in the state. The United Nations mentioned that this approach brought water back to 1,000 villages across the State. Five rivers that used to run dry after the annual monsoon season are now flowing again and fisheries are re-established. Additionally, the groundwater levels rose by an estimated six metres; productive farmland increased from $20 \%$ to $80 \%$ of the catchment; the return of wildlife such as antelope and leopard has been observed ${ }^{167}$. Biodiversity urban parks in India are common NbS-based adaptation typologies for the urban centres ${ }^{157}$. A prominent example is Kochi's Cities4forests initiative, which helps conserve, manage, restore; develop green patches by investing in urban parks, green corridors, watersheds, and forests ${ }^{168}$. Delhi's climate action plan also mentions similar $\mathrm{NbS}$ through trees plantation. Currently, very few interventions explicitly consider $\mathrm{NbS}$ in sustainable urbanisation in India 157,169,170, but the successful examples in Kochi and Delhi could be used to inspire further initiatives.

A transformational and visionary approach to building urban green infrastructure by investing in $\mathrm{NbS}$ across sectors could form an important contribution to India's climate response. For example, urban agriculture could provide mitigation benefits (carbon sequestration, air quality improvement, lower food miles), adaptation co-benefits (reduced impacts of heatwaves), greater sustainability and wellbeing outcomes (potential improvements in food and nutritional security) ${ }^{169,171,172}$. National policies such as the Atal Mission for Rejuvenation and Urban Transformation (AMRUT) or Smart Cities Mission could explicitly consider climate risks or provide a steer for climate adaptation action ${ }^{157,170}$. Currently, however, there is insignificant attention to developing or restoring blue and green infrastructure in cities through $\mathrm{NbS}^{173}$. NbS as a coherent policy practice is still in its infancy. There is a lack of data and resources and a need to improve the commercial viability of projects. There is a lack of state-led initiatives to change mindsets associated with the adoption of $\mathrm{NbS}^{143,156}$. There is also an urgent need to build a knowledge base and research evidence on how NbS can help address climate risks and contribute to mitigation and adaptation efforts to move from pilot stages and be scaled up to cover wider geographies ${ }^{162}$. More importantly, awareness and capacity building among key stakeholders such as business and society leaders, political figures and policymakers, about the benefits of adopting $\mathrm{NbS}$ is a necessary step for a net-zero future.

\section{Surface transport}

The Indian vehicular fleet is characteristic of emerging economies. India has roughly 250 million vehicles, of which $79 \%$ comprises two-wheelers. Three-wheelers like autos and tempos represent $4 \%$ of the total number of vehicles in the goods and passenger categories. Economic cars (costing less than ₹1 million USD 13,600) and premium four-wheelers cars (costing more than ₹1 million USD 13,600) represent $12 \%$ and $2 \%$. Buses and trucks represent $3 \%$ of the total number of vehicles ${ }^{174}$. The demand for internal combustion engine vehicle has more than doubled the transport sector's energy consumption and related emissions since 2010 and more than tripled since $2000^{107,154}$.

India's NDCs reflect that transport is one of the main action areas for decarbonisation, although no specific mitigation target is set ${ }^{175}$. The transition to electric mobility is guided by three main imperatives-energy security, curbing local air pollution, and curtailing GHG emissions from the transport sector ${ }^{176}$. It currently contributes to $10 \%$ 
of the country's total fuel combustion emissions ${ }^{174}$. Decarbonising surface transportation not just affects the automotive industry in India but impacts the forward and backward linkages of the transportation system like petroleum production, electricity generation, electronics manufacturing and public financing on account of change in oil import bill and fuel-tax revenue ${ }^{177}$. India is the $4^{\text {th }}$ largest passenger vehicle producer in the world. The automobile sector contributed around $7.1 \%$ to India's GDP in 2020, generated around 35 million direct and indirect jobs, and accounts for $40 \%$ of global R\&D and $4.3 \%$ of the nation's exports ${ }^{178}$.

India set an ambitious target of $30 \%$ electrification of its entire vehicle fleet by 2030 , as per NITI Aayog ${ }^{174}$. The Indian EV policy context is shaped by a relative abundance of exploitable renewable energy resources. 'Make in India' initiatives ensure high availability of skilled workforce and technology in manufacturing and IT software ${ }^{174}$. It provides added incentive towards digitisation and reducing import dependencies of EV technologies. However, the central issues associated with this EV transition vision lies with cost, manufacturing capabilities, supply chain of motors, batteries and control systems, charging infrastructure and grid integration of EVs, heavy reliance on imports and accounting specific vehicle needs of Indian consumers.

The present EV policy aims to reduce primary oil consumption in transportation, facilitate customer adoption of electric and clean energy vehicles, encourage cutting edge technology in India through adoption, adaptation, and research and development, improve transportation used by the commoner for personal and goods transport, reduce pollution in cities create battery and EV manufacturing capacity that is of global scale and competitiveness and facilitate employment growth in a solar energy sector ${ }^{174,179}$.

The current EV technologies are available for the premium segment only. In the short term, the Indian government envisages such early adoption by premium customers to pave the way for consumer comfort with electrification, raise aspirations for indigenous products, and make advanced technology available and affordable in the market ${ }^{107,171}$. In the long term, the focus can be on establishing technological and manufacturing leadership in the economic segment of the EV market.

The government has the Faster Adoption and Manufacturing of (Hybrid \&) Electric Vehicles in India (FAME II) framework to focus on this aspect of EV transition ${ }^{107,180 .}$ The other critical aspect, especially for the Indian context, is the market for shared mobility. For example, taxi aggregators such as Ola and Uber increased from 130 million rides in 2015 to 500 million rides in 2016 . It defines a new space for economic EV utilisation and creates natural and large-scale purchases of EVs ${ }^{174}$.

India's rail infrastructure is already largely electrified with a share of $54 \%$ of conventional passenger demand and $65 \%$ of freight transported on electrified trains ${ }^{181}$. However, significant investment is required to enable full electrification of the railway network $^{107}$. On the one hand, the effect of FAME II can already be seen in electric two and three-wheeler adoption, with Light Duty Vehicle (LDV) further accelerating the EV transition ${ }^{154,180}$. On the other hand, decarbonising heavy duty vehicles (HDVs), particularly long-range trucks, poses a much more significant challenge for India ${ }^{176,180}$. 
A significant challenge that India is facing is to make EVs economically viable ${ }^{174}$. The Indian government suggests reducing battery cost per kilowatt-hour basis by investing in research and development of new battery chemistry or selecting appropriate battery chemistries from existing technologies ${ }^{154,174}$. To reduce the number of batteries that EVs need, India must provide adequate charging infrastructure and increase efficiency of the vehicles ${ }^{154,174}$. The government also plans to explore potential avenues of fiscal support to accelerate EV adoption, but such policy frameworks are yet to be formed.

In the net-zero discourse, India should consider the impact of large-scale EV adoption into the power grid ${ }^{154}$. EV-led grid congestion could lead to power system failure with a significant share of variable renewable generation, especially when India aims for $450 \mathrm{GW}$ of renewable generation by $2030^{9,154}$. Digitisation can provide EV-load management through controlled charging that moderates the risks of grid congestion and could displace peak demand by $8 \mathrm{GW}$ for India ${ }^{154}$. IEA analysis ${ }^{154}$ has shown that shifting EV charging outside of the 18:00 - 22:00 (evening charging) period would help reduce the burden on the electric generation capacity needed to meet the peak demand. If $80 \%$ of EV charging needs are met during the evening period it will add 20 GW to peak load in India by $2030^{155}$; if this is shifted to the 23:00 - 05:00 (night charging) period, the contribution of EVs to peak load falls significantly ${ }^{154}$. Therefore, such system integration aspects must be considered while decarbonising the entire vehicle fleet.

Opportunities also lie in EV manufacturing, supply chain and creation of consumer segments. Government-led initiatives like 'Go Electric' campaign are important to that could help in reducing the import dependence of our country in the coming years.

The transition away from emissions intensive vehicles will also help India achieve SDG 3.9 (Substantially reduce the number of deaths and illnesses from hazardous chemicals and air, water, and soil pollution and contamination) and SDG 11.6 (reduce the adverse per capita environmental impact of cities, including by paying special attention to air quality and municipal and other waste management).

\section{Definitions of key terms}

Mitigation The lessening of the potential adverse impacts of physical hazards through actions that reduce hazard, exposure, and vulnerability.

Adaptation The process of adjustment to actual or expected climate and its effects, in order to moderate harm or exploit beneficial opportunities.

Resilience The ability of a system and its component parts to anticipate, absorb, accommodate or re- cover from the effects of a hazardous event in a timely and efficient manner while retaining the same basic structure and ways of functioning, the capacity for self-organization and the capacity to adapt to stress and change.

Vulnerability The degree to which a system is susceptible to, or unable to cope with, adverse effects of climate change, including climate variability and extremes. 
Risk The potential for consequences where something of value is at stake and where the outcome is uncertain, recognizing the diversity of values. Risk is often represented as probability or likelihood of occurrence of hazardous events or trends multiplied by the impacts if these events or trends occur.

\section{Acknowledgements}

This country profile was written by Dr Ramit Debnath (Centre for Natural Materials Innovation, University of Cambridge, UK), with input from in-country academic experts Professor Ambuj Sagar (Indian Institute of Technology, India) and Dr Suresh Babu (Dr B R Ambedkar University, India), in the context of the BEIS COP26 Futures We Want project. The production of the document was supported by project teams at Cambridge Zero (University of Cambridge) and Deloitte. The authors thank Tamara Janes (Met Office, UK) and Professor Krishna AchutaRao (Indian Institute of Technology, India) for their reviews, which significantly improved the quality of this manuscript.

\section{6. $\quad$ References}

1. MoEFCC. India: Third Biennial Update Report to the United Nations Framework Convention on Climate Change.

https://unfccc.int/sites/default/files/resource/INDIA_\%20BUR-

3_20.02.2021_High.pdf (2021).

2. Dhar, S., Pathak, M. \& Shukla, P. R. Transformation of India's steel and cement industry in a sustainable $1.5^{\circ} \mathrm{C}$ world. Energy Policy 137, 111104 (2020).

3. MoSPI. Sector-wise GDP of India. StatisticsTimes

https://statisticstimes.com/economy/country/india-gdp-sectorwise.php (2021).

4. NITIAayog. Strategy for New India@75. 232

http://niti.gov.in/sites/default/files/2019-01/Strategy_for_New_India_2.pdf (2018).

5. Majumdar, R. Recovery amid a rising state of dichotomy. Deloitte India https://www2.deloitte.com/us/en/insights/economy/asia-pacific/india-economicoutlook.html (2021).

6. UKBIC. Emerging Sectors: UK India Business Council.

https://www.ukibc.com/india-guide/why-india/emerging-sectors/ (2018).

7. Bouw, B. India 2020: 5 Sectors Driving The Country's Growth. Forbes https://www.forbes.com/sites/oppenheimerfunds/2017/05/31/india-2020-5sectors-driving-the-countrys-growth/?sh=248374602fae (2017). 
8. Chhabra, D., Garg, S. K. \& Singh, R. K. Analyzing alternatives for green logistics in an Indian automotive organization: A case study. J. Clean. Prod. 167, 962-969 (2017).

9. IEA. India Energy Outlook 2021. https://www.iea.org/reports/india-energyoutlook-2021 (2021).

10. OEC. India country profile. The Observatory of Economic Complexity https://oec.world/en/profile/country/ind (2019).

11. UNDP. Human Development Report: Briefing note for India. (2020).

12. Gol. National Action Plan on Climate Change. 56

https://archivepmo.nic.in/drmanmohansingh/climate_change_english.pdf (2008).

13. Patra, J. Review of Current and Planned Adaptation Action in India. 92 https://idl-bnc-idrc.dspacedirect.org/bitstream/handle/10625/55866/IDL55866. pdf?sequence=1\&isAllowed=y (2016).

14. UNDP. UNDP Climate change adaptation: India. https://www.adaptationundp.org/explore/india (2021).

15. Ritchie, H. \& Roser, M. India: CO2 Country Profile. Our world in Data https://ourworldindata.org/co2/country/india (2021).

16. Climatewatch. Historical GHG Emissions: India. climatewatch.org https://www.climatewatchdata.org/ghgemissions?breakBy=countries\&calculation=PER_GDP\&chartType=line\&end_ye ar=2018\&regions $=$ IND\&sectors $=$ total-excludinglucf\&source=CAIT\&start_year=1990 (2021).

17. Roxy, M. K. et al. Drying of Indian subcontinent by rapid Indian Ocean warming and a weakening land-sea thermal gradient. Nat. Commun. 6, 7423 (2015).

18. Sahu, S., Sett, M. \& Kjellstrom, T. Heat exposure, cardiovascular stress and work productivity in rice harvesters in India: implications for a climate change future. Ind. Health 51, 424-431 (2013).

19. CCA. Climate risk in India: Country profile. https://www.climatelinks.org/sites/default/files/asset/document/2017_USAID\%20 ATLAS_Climate\%20Risk\%20Profile\%20-\%20India.pdf (2017).

20. Campbell, S., Remenyi, T. A., White, C. J. \& Johnston, F. H. Heatwave and health impact research: A global review. Health Place 53, 210-218 (2018).

21. Avashia, V. \& Garg, A. Implications of land use transitions and climate change on local flooding in urban areas: An assessment of 42 Indian cities. Land Use Policy 95, 104571 (2020). 
22. Bahadur, A., Lovell, E., \& Pichon, F. Strengthening disaster risk management in India: A review of five state disaster management plans. $48 \mathrm{https}: / / \mathrm{cdkn} .0 \mathrm{rg} / \mathrm{wp}-$ content/uploads/2016/07/India-disaster-management-web.pdf (2016).

23. Mukherjee, S., Aadhar, S., Stone, D. \& Mishra, V. Increase in extreme precipitation events under anthropogenic warming in India. Weather Clim. Extrem. 20, 45-53 (2018).

24. Moors, E., Singh, T., Siderius, C., Balakrishnan, S. \& Mishra, A. Climate change and waterborne diarrhoea in northern India: Impacts and adaptation strategies. Sci. Total Environ. 468-469, S139-S151 (2013).

25. Dhiman, R. C., Pahwa, S., Dhillon, G. P. S. \& Dash, A. P. Climate change and threat of vector-borne diseases in India: are we prepared? Parasitol. Res. 106, 763-773 (2010).

26. Campbell-Lendrum, D., Manga, L., Bagayoko, M. \& Sommerfeld, J. Climate change and vector-borne diseases: what are the implications for public health research and policy? Philos. Trans. R. Soc. B Biol. Sci. 370, (2015).

27. Krishnan, R. et al. obCnFr. Clim. Dyn. 47, 1007-1027 (2016).

28. Sapkota, T. B. et al. Cost-effective opportunities for climate change mitigation in Indian agriculture. Sci. Total Environ. 655, 1342-1354 (2019).

29. Gol. India: Second national communication to the United Nations Framework Convention on Climate Change. 340 https://unfccc.int/resource/docs/natc/indnc2.pdf (2012).

30. Mbow, C. et al. Climate Change and Land: an IPCC special report on climate change, desertification, land degradation, sustainable land management, food security, and greenhouse gas fluxes in terrestrial ecosystems. 114 https://www.ipcc.ch/srccl/chapter/chapter-5/ (2019).

31. Myers, S. S. et al. Increasing CO2 threatens human nutrition. Nature 510, 139142 (2014).

32. Pathak, H., Aggarwal, P.K., \& Singh, S.D. Climate Change Impact, Adaptation and Mitigation in Agriculture: Methodology for Assessment and Application. 322 (2012).

33. Naresh Kumar, S. \& Aggarwal, P. K. Climate change and coconut plantations in India: Impacts and potential adaptation gains. Agric. Syst. 117, 45-54 (2013).

34. Pragna, P. et al. Heat stress and dairy cow: impact on both milk yield and composition. Int. J. Dairy Sci. 12, 1-11 (2017).

35. Olsson, L. et al. Land Degradation. In: Climate Change and Land: an IPCC special report on climate change, desertification, land degradation, sustainable 
land management, food security, and greenhouse gas fluxes in terrestrial ecosystems. 92 https://www.ipcc.ch/srccl/chapter/chapter-4/ (2019).

36. IPCC. Sea Level Rise and Implications for Low-Lying Islands, Coasts and Communities. In: IPCC Special Report on the Ocean and Cryosphere in a Changing Climate. 126 https://www.ipcc.ch/site/assets/uploads/sites/3/2019/11/08_SROCC_Ch04_FIN AL.pdf (2019).

37. Chitale, V. S., Behera, M. D. \& Roy, P. S. Future of Endemic Flora of Biodiversity Hotspots in India. PLOS ONE 9, e115264 (2014).

38. Malcolm, J. R., Liu, C., Neilson, R. P., Hansen, L. \& Hannah, L. Global Warming and Extinctions of Endemic Species from Biodiversity Hotspots. Conserv. Biol. 20, 538-548 (2006).

39. Satendra \& Kaushik, A.D. Forest fire disaster management. 302 https://nidm.gov.in/pdf/pubs/forest\%20fire.pdf (2014).

40. World Bank. India : Unlocking Opportunities for Forest-Dependent People in India. https://openknowledge.worldbank.org/handle/10986/8416 (2005).

41. Alongi, D. M. The Impact of Climate Change on Mangrove Forests. Curr. Clim. Change Rep. 1, 30-39 (2015).

42. Ahmed, M. \& Suphachalasai, S. Assessing the costs of climate change and adaptation in South Asia.

https://www.adb.org/sites/default/files/publication/42811/assessing-costsclimate-change-and-adaptation-south-asia.pdf (2014).

43. NOAA. India heat wave kills thousands. https://www.climate.gov/newsfeatures/event-tracker/india-heat-wave-kills-thousands (2015).

44. Bolch, T. et al. The State and Fate of Himalayan Glaciers. Science 336, 310 314 (2012).

45. Climate change adaptation implications for drought risk mitigation: a perspective for India | SpringerLink. https://link.springer.com/article/10.1007/s10584-0079330-8.

46. Panda, A. Exploring climate change perceptions, rainfall trends and perceived barriers to adaptation in a drought affected region in India. Nat. Hazards $\mathbf{8 4}$, 777-796 (2016).

47. FAO. AQUASTAT Country Profile - India. 23 http://www.fao.org/3/ca0394en/CA0394EN.pdf (2015).

48. Ali, H., Mishra, V. \& Pai, D. S. Observed and projected urban extreme rainfall events in India. J. Geophys. Res. Atmospheres 119, 12,621-12,641 (2014). 
49. IPCC. Freshwater resources. In: Climate Change 2014: Impacts, Adaptation, and Vulnerability. Part A: Global and Sectoral Aspects. Contribution of Working Group II to the Fifth Assessment Report of the Intergovernmental Panel on Climate Change. (Cambridge University Press, 2014).

50. Woetzel, J et al. Will India get too hot to work? (2020).

51. Muthukumara, M., Bandyopadhyay, S., Chonabayashi, S., Markandya, A., \& Mosier, T. South Asia's Hotspots : Impacts of Temperature and Precipitation Changes on Living Standards.

https://openknowledge.worldbank.org/handle/10986/28723 (2018).

52. Woetzel, J et al. Climate risk and exposure: Physical hazards and socioeconomic impacts.

https://www.mckinsey.com/ /media/mckinsey/business $\% 20$ functions/sustainabil ity/our\%20insights/climate\%20risk\%20and\%20response\%20physical\%20hazar ds\%20and\%20socioeconomic\%20impacts/mgi-climate-risk-and-response-fullreport-vf.pdf (2020).

53. Springmann, M. et al. Global and regional health effects of future food production under climate change: a modelling study. The Lancet 387, 19371946 (2016).

54. NIC. India: Impact of climate change to 2030. A comissioned research report. https://www.dni.gov/files/documents/climate2030_india.pdf (2009).

55. Kulp, S. A. \& Strauss, B. H. New elevation data triple estimates of global vulnerability to sea-level rise and coastal flooding. Nat. Commun. 10, 4844 (2019).

56. Knutson, Thomas R. et al. G. https://zenodo.org/record/4570334 (2021) doi:10.5281/ZENODO.4570334.

57. Krishnan, R. et al. Deciphering the desiccation trend of the South Asian monsoon hydroclimate in a warming world. Clim. Dyn. 47, 1007-1027 (2016).

58. Azam, Mohd. F. et al. Glaciohydrology of the Himalaya-Karakoram. Science 373, eabf3668 (2021).

59. Harrison, S. et al. awyrro. The Cryosphere 12, 1195-1209 (2018).

60. Watts, N. et al. The 2018 report of the Lancet Countdown on health and climate change: shaping the health of nations for centuries to come. The Lancet 392, 2479-2514 (2018).

61. IPCC. Global Warming of $1.5^{\circ} \mathrm{C}$ :An IPCC Special Report on the impacts of global warming of $1.5^{\circ} \mathrm{C}$ above pre-industrial levels and related global greenhouse gas emission pathways, in the context of strengthening the global response to the threat of climate change, sustainable development, and efforts to eradicate poverty. 
https://www.ipcc.ch/site/assets/uploads/sites/2/2019/06/SR15_Full_Report_Hig h_Res.pdf (2018).

62. Sannigrahi, S. et al. Examining the effects of forest fire on terrestrial carbon emission and ecosystem production in India using remote sensing approaches. Sci. Total Environ. 725, 138331 (2020).

63. World Bank. India: Climate Change Impacts. https://www.worldbank.org/en/news/feature/2013/06/19/india-climate-changeimpacts (2013).

64. Gupta, I. \& Chowdhury, S. Economic burden of malaria in India: The need for effective spending. WHO South-East Asia J. Public Health 3, 95 (2014).

65. CarbonCopy. Indian business and climate change - survey results. https://www.actu-environnement.com/media/pdf/news-29564-indian-businessclimate-change.pdf (2015).

66. Luo, T., Krishnan, D., \& Sen, S. Parched power: Water demands, risks, and opportunities for India's power system. 40 https://www.wri.org/parched-powerwater-demands-risks-and-opportunities-indias-power-sector (2018).

67. CDP. Building back greener: India Inc. demonstrates climate resilience. 68 (2021).

68. ETEnergyWorld. Indian firms to face Rs 7,138-bn impact in next 5 years due to climate change: Report. (2021).

69. GSI. The impact of climate change on India'a Agriculture, food security and agricultural trade. https://www.globalriskintel.com/reports/impact-climatechange-indias-agriculture-food-security-and-agricultural-trade (2019).

70. FAO. Gahaowntua. (2018).

71. Bailey, R \& Wellesley, L. Chokepoints and vulnerabilities in global food trade. (2019).

72. Baird, R. The Impact of Climate Change on Minorities and Indigenous People. https://minorityrights.org/wp-content/uploads/old-site-downloads/download-524The-Impact-of-Climate-Change-on-Minorities-and-Indigenous-Peoples.pdf (2008).

73. Bhaduri, A. Impact of climate change on life and livelihood of Dalits. 53 https://rightsandresources.org/wp-content/exported-pdf/ncdhrclimatechange.pdf (2013).

74. IPCC. Managing the Risks of Extreme Events and Disasters to Advance Climate Change Adaptation.

https://www.ipcc.ch/site/assets/uploads/2018/03/SREX_Full_Report-1.pdf (2012). 
75. SOMANATHAN, E. \& SOMANATHAN, R. Climate Change: Challenges Facing India's Poor. Econ. Polit. Wkly. 44, 51-58 (2009).

76. Paul, L. M. Addressing caste discrimination in Humanitarian Response.

http://idsn.org/wp-content/uploads/user_folder/pdf/New_files/India/2012/IDSNEU_study_on_CBD_in_humanitarian_response_by_NDW.pdf (2011).

77. MRGI. Minority and Indigenous Trends 2019: Focus on climate justice. https://cms.emergency.unhcr.org/documents/11982/44027/MRG+International\% 2C+Minority+and+Indigenous+Trends+\%282019\%29/7650d14b-a767-46db8c71-288192956f07 (2019).

78. Macchi, M., Gurung, A. M. \& Hoermann, B. Community perceptions and responses to climate variability and change in the Himalayas. Clim. Dev. 7, 414-425 (2015).

79. UNDP. India's second national communication results and outputs. https://www.climateandforests-undp.org/projects/indias-second-nationalcommunication-may-2012 (2012).

80. Gol. Report on policies and action plan for a secure and sustainable agriculture. (2019).

81. Dash, S. et al. Effect of heat stress on reproductive performances of dairy cattle and buffaloes: A review. Vet. World 9, 235-244 (2016).

82. Barrett, N. W. et al. Effects of acute and chronic heat stress on the performance, egg quality, body temperature, and blood gas parameters of laying hens. Poult. Sci. 98, 6684-6692 (2019).

83. Srinivasarao, Ch. Why India needs climate resilient agriculture systems. DownToEarth (2021).

84. Lv, C., Huang, Y., Sun, W., Yu, L. \& Zhu, J. pi. Eur. J. Agron. 112, 125961 (2020).

85. Singh, K., McClean, C. J., Büker, P., Hartley, S. E. \& Hill, J. K. Mapping regional risks from climate change for rainfed rice cultivation in India. Agric. Syst. 156, 76-84 (2017).

86. MoF. Economic Survey 2017-18 (Volume 1 and Volume 2). (Oxford University Press, 2018).

87. MoAFW. All India Report on Agriculture Census 2015-16. (2020).

88. Joshi, P. K. \& Tyagi, N. K. Small Farm Holders and Climate Change: Overcoming the Impacts in India. in Climate Smart Agriculture in South Asia: Technologies, Policies and Institutions (eds. Pal, B. D., Kishore, A., Joshi, P. K. \& Tyagi, N. K.) 49-72 (Springer, 2019). doi:10.1007/978-981-10-8171-2_3. 
89. Gupta, R., Somanathan, E. \& Dey, S. Global warming and local air pollution have reduced wheat yields in India. Clim. Change 140, 593-604 (2017).

90. Timperley, J. The Carbon Brief Profile: India. https://www.carbonbrief.org/thecarbon-brief-profile-india (2019).

91. Timperley, J \& Pearce, R. Mapped: Where multilateral climate funds spend their money. https://www.carbonbrief.org/mapped-where-multilateral-climate-fundsspend-their-money (2017).

92. IISD. India's Energy Transition: Stranded coal power assets, workers and energy subsidies. (2019).

93. IIED. Avoiding New Poverty: Mining-Induced Displacement and Resettlement. (2002).

94. ODI. Position paper. Beyond coal: Scaling up clean energy to fight global povert. (2016).

95. PowerforAll. Renewable Energy Jobs in Sub-Saharan Africa and Asia 2019. (2019).

96. Das, P. et al. Flexibility requirement for large-scale renewable energy integration in Indian power system: Technology, policy and modeling options. Energy Strategy Rev. 29, 100482 (2020).

97. Tripathi, B. Why an economy-wide net-zero emission target won't work for India. Business-Standard (2020).

98. Dubash, N. K., Khosla, R., Kelkar, U. \& Lele, S. India and Climate Change: Evolving Ideas and Increasing Policy Engagement. Annu. Rev. Environ. Resour. 43, 395-424 (2018).

99. Debnath, R., Mittal, V. \& Jindal, A. A review of challenges from increasing renewable generation in the Indian Power Sector: Way forward for Electricity (Amendment) Bill 2020. Energy Environ. 0958305X20986246 (2021) doi:10.1177/0958305X20986246.

100. Watts, N. et al. The 2020 report of The Lancet Countdown on health and climate change: responding to converging crises. The Lancet 397, 129-170 (2021).

101. Barik, P., Naoghare, P., Sivanesan, S., Kannan, K. \& Middey, A. Increased average annual prevalence of upper respiratory tract infection (UTRI) in the central Indian population residing near the coal-fired thermal power plants. $S N$ Appl. Sci. 3, 214 (2021).

102. Burney, J. \& Ramanathan, V. Recent climate and air pollution impacts on Indian agriculture. Proc. Natl. Acad. Sci. 111, 16319-16324 (2014). 
103. Ghanekar, N. What Is A Net Zero Emissions Pledge \& Does India Benefit From It? EarthCheck https://www.indiaspend.com/earthcheck/what-is-a-net-zeroemissions-pledge-does-india-benefit-from-it-741388 (2021).

104. Bhadwal, S., Sharma, G., Gorti, G. \& Sen, S. M. a. Environ. Dev. 31, 68-77 (2019).

105. Bhagwat, P., Yemane, H. S. \& Bhagwat, S. Charging up India's electric vehicles. (2020).

106. PIB. boio. (2021).

107. IEA. India 2020: Energy Policy Review. 305

https://niti.gov.in/sites/default/files/2020-01/IEA-India\%202020-In-depthEnergyPolicy_0.pdf (2020).

108. Shell and TERI. INDIA: Transforming to a net-zero emissions energy systems Scenario Sketch. 56 https://www.shell.in/promos/energy-and-innovation/indiascenario-

sketch/jcr_content.stream/1617850096430/4dc1d51b4d29c3dfea47f0a57e9eef $62000 \mathrm{a0} 21 \mathrm{~b} /$ india-transforming-to-a-net-zero-emissions-energy-systemscenario-sketch-report.pdf (2020).

109. INCCA. India: Greenhouse Gas Emissions 2007. (2010).

110. Kennedy, J. \& King, L. The political economy of farmers' suicides in India: indebted cash-crop farmers with marginal landholdings explain state-level variation in suicide rates. Glob. Health 10, 16 (2014).

111. Tripathi, A. \& Mishra, A. K. Knowledge and passive adaptation to climate change: An example from Indian farmers. Clim. Risk Manag. 16, 195-207 (2017).

112. CIPHET. Vision 2025 - CIPHET Perspective Plan. 74 (2007).

113. Davis, K. F. et al. Assessing the sustainability of post-Green Revolution cereals in India. Proc. Natl. Acad. Sci. 116, 25034-25041 (2019).

114. Pingali, P. L. Green Revolution: Impacts, limits, and the path ahead. Proc. Natl. Acad. Sci. 109, 12302-12308 (2012).

115. Boettiger, S. \& Sanghvi, S. How digital innovation is transforming agriculture: Lessons from India. (2019).

116. Ganguly, K., Gulati, A., \& von Braun, J. Innovations spearheading the next transformations in India's agriculture.

https://www.econstor.eu/bitstream/10419/187465/1/zef-wp-159.pdf (2017). 
117. Rao, N. H. Big data and climate smart agriculture - status and implications for agricultural research and innovation in India. Proc. Indian Natl. Sci. Acad. 84, 625-640 (2018).

118. Yadava, D. K., Hossain, F. \& Mohapatra, T. Nutritional security through crop biofortification in India: Status \& future prospects. Indian J. Med. Res. 148, 621631 (2018).

119. Nath, P. K. \& Behera, B. A critical review of impact of and adaptation to climate change in developed and developing economies. Environ. Dev. Sustain. 13, 141-162 (2011).

120. FAO. The impact of disasters and crises on agriculture and food security. http://www.fao.org/3/cb3673en/cb3673en.pdf (2021).

121. Bhan, S. \& Behera, U. K. Conservation agriculture in India - Problems, prospects and policy issues. Int. Soil Water Conserv. Res. 2, 1-12 (2014).

122. Pradhan, A., Chan, C., Roul, P. K., Halbrendt, J. \& Sipes, B. Potential of conservation agriculture (CA) for climate change adaptation and food security under rainfed uplands of India: A transdisciplinary approach. Agric. Syst. 163, 27-35 (2018).

123. Singh, R. \& Singh, G. S. Traditional agriculture: a climate-smart approach for sustainable food production. Energy Ecol. Environ. 2, 296-316 (2017).

124. FAO. "Climate-Smart" Agriculture: Policies, Practices and Financing for Food Security, Adaptation and Mitigation. 49 http://www.fao.org/3/i1881e/i1881e00.pdf (2010).

125. Khatri-Chhetri, A., Aggarwal, P. K., Joshi, P. K. \& Vyas, S. Farmers' prioritization of climate-smart agriculture (CSA) technologies. Agric. Syst. 151, 184-191 (2017).

126. Urge-Vorsatz, D. et al. Best Practice Policies for Low Energy and Carbon Buildings: A Scenario Analysis. Research report prepared by the Center for Climate Change and Sustainable Policy (3CSEP) for the Global Buildings Performance Network. (Central European University Press, 2012).

127. Maisonneuve, C. \& Dek, M. Housing for All in India. OECD Work. Pap. (2020).

128. Bardhan, R., Sarkar, S., Jana, A. \& Velaga, N. R. Mumbai slums since independence: Evaluating the policy outcomes. Habitat Int. 50, 1-11 (2015).

129. IEA. The Future of Cooling. https://www.iea.org/reports/the-future-of-cooling (2018).

130. Shastri, H., Barik, B., Ghosh, S., Venkataraman, C. \& Sadavarte, P. Flip flop of Day-night and Summer-Winter Surface Urban Heat Island Intensity in India. Sci. Rep. 7, 40178 (2017). 
131. UN Environment and IEA. Towards a zero-emission, efficient, and resilient buildings and construction sector. Global Status Report 2017.

https://www.worldgbc.org/sites/default/files/UNEP\%20188_GABC_en\%20\%28w eb\%29.pdf (2017).

132. Graham, P. \& Rawal, R. Achieving the $2^{\circ} \mathrm{C}$ goal: the potential of India's building sector. Build. Res. Inf. 47, 108-122 (2019).

133. Abhyankar, N., Shah, N., Park, W.Y., \& Phadke, A. Accelerating energy efficiency improvements in room air conditioners in India: Potential, costsbenefits, and policies. https://escholarship.org/uc/item/8710154k (2017).

134. Debnath, R., Bardhan, R. \& Sunikka-Blank, M. How does slum rehabilitation influence appliance ownership? A structural model of non-income drivers. Energy Policy 132, 418-428 (2019).

135. Bardhan, R., Debnath, R., Gama, J. \& Vijay, U. REST framework: A modelling approach towards cooling energy stress mitigation plans for future cities in warming Global South. Sustain. Cities Soc. 61, 102315 (2020).

136. Diddi, S. Scenarios of energy conservation building code (ECBC) in India. (2017).

137. Khosla, R. \& Chunekar, A. Plugging In: A Collection of Insights on Electricity Use in Indian Homes. (2017).

138. Khosla, R., Sagar, A. \& Mathur, A. Deploying Low-carbon Technologies in Developing Countries: A view from India's buildings sector. Environ. Policy Gov. 27, 149-162 (2017).

139. de la Rue du Can, S. et al. Modeling India's energy future using a bottom-up approach. Appl. Energy 238, 1108-1125 (2019).

140. Ockwell, D., Sagar, A. \& de Coninck, H. Collaborative research and development (R\&D) for climate technology transfer and uptake in developing countries: towards a needs driven approach. Clim. Change 131, 401-415 (2015).

141. Ürge-Vorsatz, D. et al. Advances Toward a Net-Zero Global Building Sector. Annu. Rev. Environ. Resour. 45, 227-269 (2020).

142. IPCC. AR5 Climate Change 2014: Mitigation of Climate Change. https://www.ipcc.ch/report/ar5/wg3/ (2014).

143. Lafortezza, R. \& Sanesi, G. Nature-based solutions: Settling the issue of sustainable urbanization. Environ. Res. 172, 394-398 (2019).

144. MoEFCC. India Cooling Action Plan. http://ozonecell.nic.in/wpcontent/uploads/2019/03/INDIA-COOLING-ACTION-PLAN-e-circulationversion080319.pdf (2019). 
145. NAZCA. NAZCA Global Climate Action: India.

http://climateaction.unfccc.int/views/country.html?country=IN (2021).

146. Kamat, A. S., Khosla, R. \& Narayanamurti, V. Illuminating homes with LEDs in India: Rapid market creation towards low-carbon technology transition in a developing country. Energy Res. Soc. Sci. 66, 101488 (2020).

147. Pattanayak, S. K. et al. Experimental evidence on promotion of electric and improved biomass cookstoves. Proc. Natl. Acad. Sci. 116, 13282-13287 (2019).

148. Ritchie, H. \& Roser, M. 'Energy'. Published online at OurWorldlnData.org. Our world in Data https://ourworldindata.org/energy/country/india (2020).

149. CEA. Central Electricity Authority. https://cea.nic.in/dashboard/?lang=en (2021).

150. Bardhan, R., Debnath, R. \& Jana, A. Evolution of sustainable energy policies in India since 1947: A review. Wiley Interdiscip. Rev. Energy Environ. 8, (2019).

151. Kale, S.S. Electrifying India: Regional Political Economies of Development. (Stanford University Press, 2014).

152. Kamboj, P. \& Tongia, R. Indian Railways and coal: An unsustainable interdependency. https://www.brookings.edu/research/indian-railways-and-coal/ (2018).

153. Tongia, R. \& Gross, S. Coal in India: Adjusting to transition. https://thinkasia.org/handle/11540/9782 (2019).

154. IEA. Global EV Outlook 2020. https://www.iea.org/reports/global-ev-outlook2020 (2020).

155. ET. How India in a short period of time has become the cheapest producer of solar power. The Economic Times (2019).

156. Seddon, N. et al. Nature-based Solutions in Nationally Determined Contributions: Synthesis and recommendations for enhancing climate ambition and action by 2020. 62

https://portals.iucn.org/library/sites/library/files/documents/2019-030-En.pdf (2019).

157. Singh, C., Madhavan, M., Arvind, J. \& Bazaz, A. Climate change adaptation in Indian cities: A review of existing actions and spaces for triple wins. Urban Clim. 36, 100783 (2021).

158. GCA. Adapt now: A global call for leadership on climate resilience. https://gca.org/wpcontent/uploads/2019/09/GlobalCommission_Report_FINAL.pdf (2019). 
159. University of Oxford. Mangrove protection in India. Nature-based Solutions Initiative https://www.naturebasedsolutionsinitiative.org/news/mangroves-inindia-provided-cyclone-protection/ (2020).

160. Khosla, R. \& Bhardwaj, A. Urbanization in the time of climate change:

Examining the response of Indian cities. WIREs Clim. Change 10, e560 (2019).

161. Rajeev, V. Man and nature in Indian Thought. Int. J. Environ. Rehabil. Conserv. IV, 50-55 (2013).

162. Preethan, P. \& Gupta, S. Nature-based Solutions for reimagining the pathway to a sustainable future. WRI India https://wri-india.org/blog/nature-based-solutionsreimagining-pathway-sustainable-future (2020).

163. Sharma, D., Singh, R., \& Singh, R. Urban Climate Resilience: A review of the methodologies adopted under the ACCCRN initiative in Indian cities. Asian Cities Clim. Resil. Work. Pap. 71 (2013).

164. MPGOV. Conservation Of Traditional Water Supply Sources In Indore City Under CCAP. http://www.climatechange.mp.gov.in/en/ongoingprojects/conservation-traditional-water-supply-sources-indore-city-under-ccap (2021).

165. Rumbach, A. At the roots of urban disasters: Planning and uneven geographies of risk in Kolkata, India. J. Urban Aff. 39, 783-799 (2017).

166. Bharucha, Z. P., Mitjans, S. B. \& Pretty, J. Towards redesign at scale through zero budget natural farming in Andhra Pradesh, India. Int. J. Agric. Sustain. 18, 1-20 (2020).

167. WWAP/UN-Water. The United Nations World Water Development Report 2018: Nature-based Solutions for Water. (UNESCO, 2018).

168. cities4forests. Cities4Forests: Kochi, India. https://cities4forests.com/cities/kochi/ (2021).

169. Zasada, I., Weltin, M., Zoll, F. \& Benninger, S. L. Home gardening practice in Pune (India), the role of communities, urban environment and the contribution to urban sustainability. Urban Ecosyst. 23, 403-417 (2020).

170. Rajasekar, U., Chakraborty, S. \& Bhat, G. Climate Resilient Smart Cities: Opportunities for Innovative Solutions in India. in Climate Change in Cities: Innovations in Multi-Level Governance (eds. Hughes, S., Chu, E. K. \& Mason, S. G.) 203-227 (Springer International Publishing, 2018). doi:10.1007/978-3319-65003-6_11.

171. Bannor, R. K., Sharma, M. \& Oppong-Kyeremeh, H. Extent of urban agriculture and food security: evidence from Ghana and India. Int. J. Soc. Econ. 48, 437455 (2021). 
172. Shahasranaman, M. Future of urban agriculture in India. http://irapindia.org/images/irap-Occasional-Paper/IRAP-Occasionalpaper10.pdf.

173. Pathak, M. \& Mahadevia, D. Urban Informality and Planning: Challenges to Mainstreaming Resilience in Indian Cities. in Resilience-Oriented Urban Planning: Theoretical and Empirical Insights (eds. Yamagata, Y. \& Sharifi, A.) 49-66 (Springer International Publishing, 2018). doi:10.1007/978-3-319-7579883 .

174. NITIAayog. Zero Emission Vehicles (ZEVs): Towards a policy framework. (2020).

175. UNFCCC. India's Intended Nationally Determined Contributions: Working towards climate justice.

https://www4.unfccc.int/sites/ndcstaging/PublishedDocuments/India\%20First/IN DIA\%20INDC\%20TO\%20UNFCCC.pdf (2015).

176. Soman, Abhinav, Kaur, H., Jain, H., \& Ganesan, K. India's Electric Vehicle Transition. 66 https://www.ceew.in/publications/india\%E2\%80\%99s-electricvehicle-transition-0 (2020).

177. ILO. World Employment and Social Outlook 2018: Greening with jobs. https://www.ilo.org/global/publications/books/WCMS_628654/lang-en/index.htm (2018).

178. Bajwa, N. Invest India: Automobile. Invest India https://www.investindia.gov.in/sector/automobile (2021).

179. TERI. Comparison of Decarbonisation Strategies for India's Land Transport Sector: An Inter Model Assessment. 37 (2019).

180. CAT. Decarbonising the Indian transport sector: pathways and policies. 79 https://climateactiontracker.org/publications/decarbonising-indian-transportsector-pathways-and-policies/ (2020).

181. Dhar, S., Pathak, M. \& Shukla, P. R. Transformation of India's transport sector under global warming of $2{ }^{\circ} \mathrm{C}$ and $1.5^{\circ} \mathrm{C}$ scenario. J. Clean. Prod. 172, 417427 (2018). 
